\title{
Therapeutic Potential of Volatile Terpenes and Terpenoids from Forests for Inflammatory Diseases
}

\author{
Taejoon Kim, Bokyeong Song, Kyoung Sang Cho * and Im-Soon Lee * \\ Department of Biological Sciences, Research Center for Coupled Human and Natural Systems for Ecowelfare, \\ Konkuk University, Seoul 05029, Korea; jusink@konkuk.ac.kr (T.K.); bokysong@konkuk.ac.kr (B.S.) \\ * Correspondence: kscho@konkuk.ac.kr (K.S.C.); islee@konkuk.ac.kr (I.-S.L.); \\ Tel.: +82-2-450-3424 (K.S.C.); +82-2-450-4213 (I.-S.L.)
}

Received: 31 January 2020; Accepted: 19 March 2020; Published: 22 March 2020

\begin{abstract}
Forest trees are a major source of biogenic volatile organic compounds (BVOCs). Terpenes and terpenoids are known as the main BVOCs of forest aerosols. These compounds have been shown to display a broad range of biological activities in various human disease models, thus implying that forest aerosols containing these compounds may be related to beneficial effects of forest bathing. In this review, we surveyed studies analyzing BVOCs and selected the most abundant 23 terpenes and terpenoids emitted in forested areas of the Northern Hemisphere, which were reported to display anti-inflammatory activities. We categorized anti-inflammatory processes related to the functions of these compounds into six groups and summarized their molecular mechanisms of action. Finally, among the major 23 compounds, we examined the therapeutic potentials of 12 compounds known to be effective against respiratory inflammation, atopic dermatitis, arthritis, and neuroinflammation among various inflammatory diseases. In conclusion, the updated studies support the beneficial effects of forest aerosols and propose their potential use as chemopreventive and therapeutic agents for treating various inflammatory diseases.
\end{abstract}

Keywords: BVOC; terpene; terpenoid; forest aerosol; anti-inflammation

\section{Introduction}

\subsection{Terpenes and Terpenoids}

Trees in forests are a major source of a broad range of biogenic volatile organic compounds (BVOCs) that constitute a large and diverse class of plant secondary metabolites [1,2]. The main role of these compounds is to protect plants from herbivores and pathogenic microorganisms by displaying direct toxicity, repelling herbivores, or attracting herbivores' enemies [3-6]. It was reported that a given plant species emits a mixture of BVOCs, which can be highly complex, containing up to 200 different compounds [7].

The majority of BVOCs emitted by plants are terpenes and terpenoids. These compounds represent one of the largest groups of plant secondary metabolites, with approximately 55,000 different structures [8]. The structure of terpenes is based on the linkage of isoprene units $\left(\mathrm{C}_{5} \mathrm{H}_{8}\right)$ such as dimethylallyl pyrophosphate and isopentenyl pyrophosphate $[9,10]$. These two $C_{5}$ building blocks generate various terpene compounds by head-to-tail condensation [11]. Depending on the number of linked isoprene units, the resulting terpenes are classified into hemi-, mono-, sesqui-, di-, sester-, tri-, sesquar-, tetra-, and polyterpenes $\left(\mathrm{C}_{5}, \mathrm{C}_{10}, \mathrm{C}_{15}, \mathrm{C}_{20}, \mathrm{C}_{25}, \mathrm{C}_{30}, \mathrm{C}_{35}, \mathrm{C}_{40}\right.$, and longer chains of $\mathrm{C}_{5}$, respectively) [12]. In contrast to terpenes that are hydrocarbons, terpenes containing additional functional groups, usually oxygen-containing are called terpenoids [13]. As deduced from their various structures, terpenes and terpenoids have been reported to exhibit diverse biological activities. Among 
them, the beneficial effects of terpene and terpenoid compounds on human health have been attracting the attention of numerous researchers, and their roles in various human disease processes, such as inflammatory diseases, tumorigenesis, and neurodegeneration, have been studied using cell and animal models for many decades, suggesting terpenes and terpenoids as potential chemopreventive and therapeutic agents for various diseases [14-16]. In recent years, small subgroups of novel terpenes and terpenoids have been isolated or synthesized, providing more potentially chemotherapeutic terpene compounds for clinical trials [17].

The terpenes and terpenoids in BVOCs can be classified into four groups: isoprenes, monoterpenes, sesquiterpenes, and oxygenated hydrocarbons [18-20]. In forested areas, monoterpenes and isoprenes are the major BVOCs that contribute to substantial emission levels to the atmosphere [21-24]. Monoterpenes are mostly emitted by coniferous species, whereas broad-leaved trees mainly emit isoprenes [25-27]. In contrast to the various beneficial effects of terpene compounds in human disease models, isoprenes have been recently shown to act as signaling molecules important for stress responses and growth in plants [28]; however, little is known about their positive effects on human health. Moreover, substantial emission of isoprene increases the production of ozone and smog in the presence of nitrogen oxides, due to its reactivity with hydroxyl radicals, adversely affecting the environment [29].

Various terpenes and terpenoids, mainly monoterpenes and sesquiterpenes, can be continuously emitted from specialized storage organs in leaves, stems, and trunks of trees, while others are synthesized de novo after invasion of a pathogen to defend the plants [30-32]. Due to medicinal effects of terpenes and terpenoids, forest bathing has been suggested to exhibit positive influences on human health via showering of forest aerosols containing the compounds, in addition to its physical relaxation effect [14]. This review summarizes the anti-inflammatory effects of 23 selected BVOCs from forests: 13 monoterpenes, 7 oxygenated monoterpenes, 1 monoterpene derivative, and 2 sesquiterpenes (Table 1). We surveyed the studies analyzing BVOCs emitted in various mixed as well as pure forests in North America (the United States), Europe (Estonia, France, and Turkey), or Asia (South Korea). These forest areas are located between latitudes 33 and 58 degrees in the Northern Hemisphere, mostly in the temperate zone that is also called as the mid-latitudes. These compounds were chosen because they are not only the major terpenes and terpenoids emitted in the forests, but also because as single compounds have beneficial effects on inflammatory processes with known molecular mechanisms. 
Table 1. General types of terpenes and terpenoids emitted from forested areas. Some of the well-known synonyms and molecular formulas are shown in brackets. All structures of the compounds are from the PubChem 3D viewer database (https://pubchem.ncbi.nlm.nih.gov), in which carbons and oxygens are colored in gray and red, respectively. For more details on the drawing, refer to the description in the Pubchem web site (https://pubchem.ncbi.nlm.nih.gov/pc3d/PC3DView1.html).

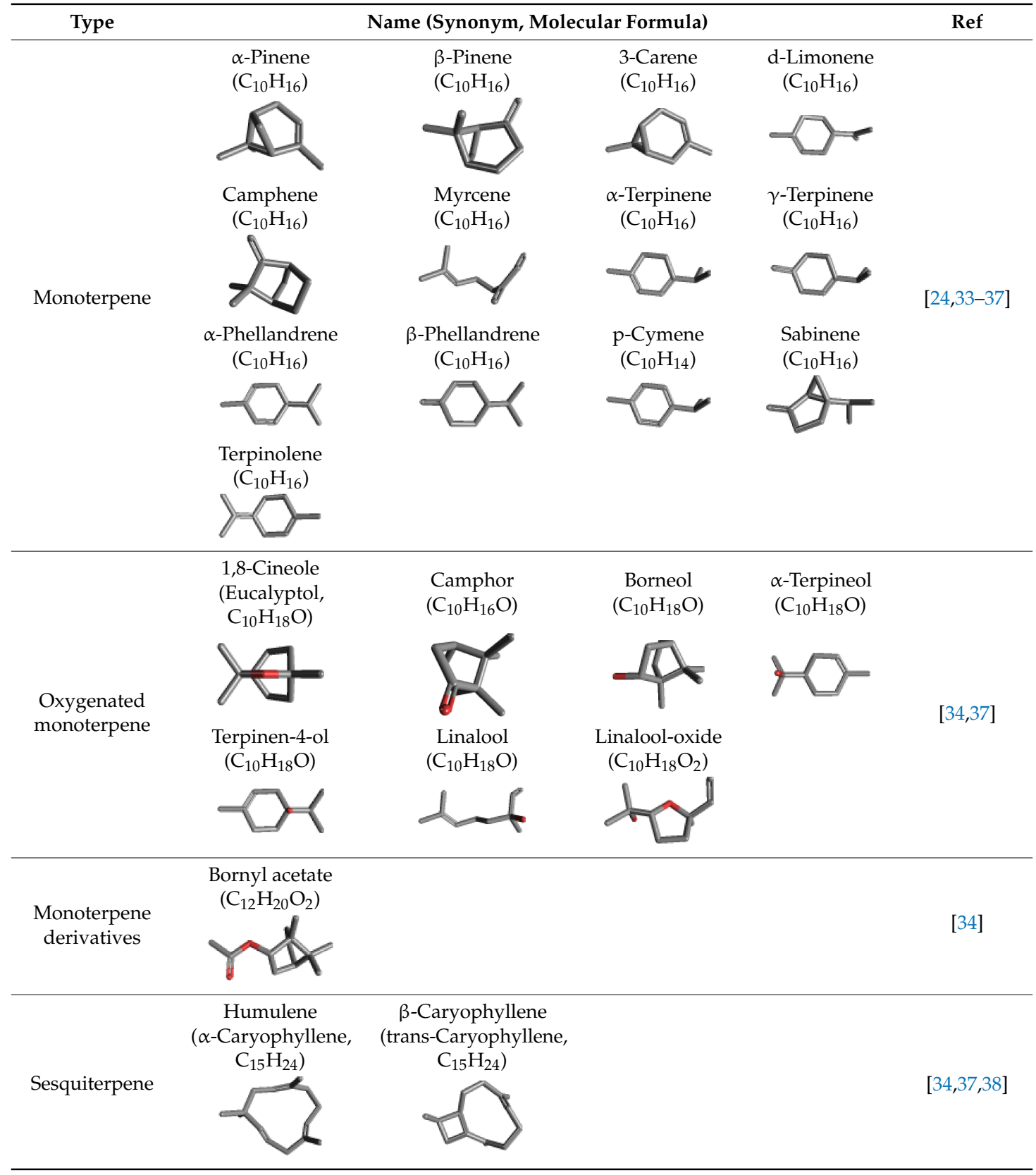

\subsection{Inflammation}

Inflammation is a protective response of the host to infections and tissue damages, mediated by the activation of various immune cells [39]. However, deregulated inflammatory responses can result in acute and chronic inflammatory diseases causing excessive or long-lasting tissue damages. Macrophages play a central role in many different immune-pathological phenomena during inflammation, including overproduction of pro-inflammatory cytokines and inflammatory mediators, such as interleukin IL-1 $\beta$, IL-6, tumor necrosis factor-alpha (TNF- $\alpha$ ), and nitric oxide (NO) synthesized by inducible NO synthase (iNOS), and prostaglandin E2 (PGE-2) synthesized by cyclooxygenase-2 (COX-2). Nuclear factor- $\mathrm{kB}$ 
$(\mathrm{NF}-\mathrm{kB})$ is a central transcription factor that regulates expression of pro-inflammatory genes during inflammation [39].

In the canonical pathway triggered by Toll-like receptors (TLRs) and proinflammatory cytokines such as TNF- $\alpha$ and IL-1, the activated NF- $\mathrm{KB}$ translocates to the nucleus and regulates the expression of the pro-inflammatory genes [40]. Additionally, the pro-inflammatory mediators activate the signal transduction pathways of the core mitogen-activated protein kinases [MAPKs: extracellular signal-regulated kinase (ERK), c-Jun N-terminal kinase (JNK) and p38], which, in turn, control various cellular processes by regulating downstream protein kinases and transcription factors [41].

Several cellular processes including oxidative stress and autophagy also play an important role in inflammation. Reactive oxygen species (ROS), produced from several sources including the mitochondria, mediates the increase in leukocyte migration and junctional permeability via various signaling mechanisms [42]. In addition, a recent study showed that ROS regulates IL- $1 \beta$ release by directly interfering with NF- $\mathrm{kB}$ signaling [43]. Autophagy, a recycling process of cytosolic materials, is also closely related to inflammation. By influencing the development, homeostasis, and survival of inflammatory cells and by affecting the generation of cytokines, autophagy plays a critical role in inflammation [44]. In addition to the above processes, other pathways can be involved in inflammation progression, such as the endoplasmic reticulum (ER) stress and microRNA regulation [45]. Since these cellular processes hold such an important role in inflammation, their regulators could also modulate inflammation.

\section{Anti-Inflammatory Effects of Volatile Terpene and Terpenoids in Forests}

Studies in recent decades have demonstrated that terpenes and terpenoids ameliorate various symptoms caused by inflammation via inhibiting various steps of inflammatory processes. In this section, we categorize the anti-inflammatory activities of 23 compounds, which are the major terpenes and terpenoids emitted in the forests, into six groups and describe studies that revealed the mechanisms of their anti-inflammatory activities at the molecular level (summarized in Table 2). 
Table 2. The anti-inflammatory activities of the major 23 terpenes and terpenoids emitted in the forests and their action mechanisms.

\begin{tabular}{|c|c|c|c|c|c|}
\hline $\begin{array}{l}\text { Related Inflammatory } \\
\text { Activities }\end{array}$ & Name & Mechanism of Action & Experimental Protocol & Animal Tested & Ref. \\
\hline \multirow{19}{*}{$\begin{array}{l}\text { Pro-inflammatory } \\
\text { mediator }\end{array}$} & \multirow{4}{*}{ d-Limonene } & TNF- $\alpha$, IL- $1 \beta$ and IL- $6 \downarrow$ & LPS-stimulation & Raw 264.7 cell line & [46] \\
\hline & & NF-kB, COX-2, iNOS and Nitrite levels $\downarrow$ & Doxorubicin-induced inflammation & Wistar rats & [47] \\
\hline & & NO levels $\downarrow$ & $A \beta 42$ expressed heads & Fruit fly & [48] \\
\hline & & NO and iNOS levels $\downarrow$ & In vitro treatment & Human chondrocytes & [49] \\
\hline & Myrcene & NO and iNOS levels $\downarrow$ & In vitro treatment & Human chondrocytes & [49] \\
\hline & \multirow{2}{*}{$\gamma$-Terpinene } & TNF- $\alpha$ and IL-1 $\beta \downarrow$ & Carrageenan-induced peritonitis model & Swiss mice & [50] \\
\hline & & IL- $1 \beta$, IL- $6 \downarrow$ and IL-10, COX-2, PGE $2 \uparrow$ & LPS-Stimulation & Macrophages from mice & [51] \\
\hline & \multirow[t]{2}{*}{$\alpha$-Phellandrene } & TNF- $\alpha$ and IL-6 $\downarrow$ & $\begin{array}{l}\text { Carrageenan injection in air pouch } \\
\text { cavities }\end{array}$ & Wistar rats or swiss mice & [52] \\
\hline & & IL-6 and TNF- $\alpha \downarrow$ NO production $\downarrow$ & LPS-stimulation & Raw 264.7 cell line & [53] \\
\hline & Terpinolene & $\begin{array}{c}\text { Pro-inflammatory cytokines IL-6 and TNF- } \alpha \downarrow \\
\text { NO production } \downarrow\end{array}$ & LPS-stimulation & Raw 264.7 cell line & [53] \\
\hline & \multirow{9}{*}{ 1,8-Cineole } & $\begin{array}{l}\text { Production of LTB4 and PGE2 from monocytes } \\
\text { ex vivo }\end{array}$ & $\begin{array}{l}\text { Stimulated with the calcium ionophore } \\
\text { A23187 measured ex vivo }\end{array}$ & $\begin{array}{l}\text { Blood monocytes of patients } \\
\text { with bronchial asthma }\end{array}$ & [54] \\
\hline & & $\begin{array}{c}\text { TNF- } \alpha \text { and IL- } 1 \beta \text {, leukotriene B4 and } \\
\text { thromboxane B2 } \downarrow\end{array}$ & LPS-and IL1 $\beta$-stimulation in vitro & Human monocytes & [55] \\
\hline & & Levels of TNF $\alpha$ and IL- $1 \beta$ in BALF $\downarrow$ & $\begin{array}{l}\text { Experimental model of airways } \\
\text { allergic inflammation }\end{array}$ & $\begin{array}{c}\text { Ovalbumin (OVA)-challenged } \\
\text { Guinea pigs }\end{array}$ & [56] \\
\hline & & TNF- $\alpha$ and IL- $1 \beta \downarrow$ and IL-10 $\uparrow$ & $\begin{array}{c}\text { Mouse LPS-induced acute lung injury } \\
\text { model }\end{array}$ & ICR mice & [57] \\
\hline & & NO $\downarrow$ TNF- $\alpha$, IL- $1 \beta$ and IL- $6 \downarrow$ & $A \beta(25-35)$ treatment & PC 12 cell line & [58] \\
\hline & & MMP-9 $\downarrow$ TNF- $\alpha$, IL-6 and NO $\downarrow$ & $\begin{array}{l}\begin{array}{l}\text { LPS-induced acute lung injury mouse } \\
\text { model }\end{array} \\
\end{array}$ & BALB/C mice & [59] \\
\hline & & $\begin{array}{l}\text { Production of interleukin IL-4, IL-13 and } \\
\text { IL-17A in BALF after Derp challenge } \downarrow\end{array}$ & $\begin{array}{l}\text { House dust mite (HDM)- induced } \\
\text { murine asthma model }\end{array}$ & BEAS-2B cell line & [60] \\
\hline & & IL- $1 \beta$, IL- 6 and TNF- $\alpha$ in BALF $\downarrow$ & Short-term cigarette smoke (CS) exposure & C57BL/6 mice & [61] \\
\hline & & $\begin{array}{l}\text { IL-4, IL-5, IL-10, and MCP-1 in nasal lavage } \\
\text { fluids } \downarrow \\
\text { IL-1 } \beta, \text { IL-6, TNF- } \alpha \text {, and IFN- } \gamma \text { in lung tissues } \downarrow\end{array}$ & Mice infected with influenza A virus & BALB/C mice & [62] \\
\hline
\end{tabular}


Table 2. Cont.

\begin{tabular}{|c|c|c|c|c|c|}
\hline $\begin{array}{l}\text { Related Inflammatory } \\
\text { Activities }\end{array}$ & Name & Mechanism of Action & Experimental Protocol & Animal Tested & Ref \\
\hline \multirow{14}{*}{$\begin{array}{l}\text { Pro-inflammatory } \\
\text { mediator }\end{array}$} & Camphor & $\begin{array}{c}\text { TNF- } \alpha, \text { IL- } 1 \beta \text { and IL- } 6 \text { in Kidney, testes, liver } \\
\text { and lung } \uparrow\end{array}$ & An acute administration & Wistar rats & [63] \\
\hline & \multirow{4}{*}{ Borneol } & $\begin{array}{c}\text { IL-1 } \beta \text { and IL-6 mRNA expression in colon } \\
\text { tissue } \downarrow\end{array}$ & TNBS-induced colitis & ICR mouse & [64] \\
\hline & & $\begin{array}{l}\text { The elevation of NO, the increase of inducible } \\
\text { iNOS enzymatic activity and the upregulation } \\
\text { of iNOS expression } \downarrow\end{array}$ & $\begin{array}{l}\text { In vitro ischemic model of } \\
\text { oxygen-glucose deprivation followed by } \\
\text { reperfusion }\end{array}$ & Wistar rats & [65] \\
\hline & & TNF- $\alpha$, IL- $1 \beta$, and IL- $6 \downarrow$ & $\begin{array}{c}\text { Mouse LPS-induced acute lung injury } \\
\text { model }\end{array}$ & $\begin{array}{l}\text { Raw } 264.7 \text { cell line } \\
\text { BALB/c mice }\end{array}$ & [66] \\
\hline & & $\begin{array}{l}\text { CD16 and CD206 expressions and levels of } \\
\text { IL-1 } \beta \text {, IL-6, TNF-a, and IL-10 proteins } \downarrow\end{array}$ & $\begin{array}{l}\text { LPS-stimulated mouse microglia and } \\
\text { septic mice }\end{array}$ & C57BL/6 mice & [67] \\
\hline & $\alpha$-Terpineol & Nitrite production $\downarrow$ & LPS-stimulation & Peritoneal macrophage & [68] \\
\hline & \multirow{2}{*}{ Terpinen-4-ol } & NF-KB and NLRP3 inflammasome $\downarrow$ & Dextran sulfate sodium-induced colitis & C57BL/6 mice & [69] \\
\hline & & $\begin{array}{l}\text { LPS-induced phosphorylation of IKB } \alpha \text { and } \\
\text { NF-kB p65 } \downarrow \text { The expression of PPAR- } \gamma \uparrow\end{array}$ & $\begin{array}{l}\text { Mouse LPS-induced acute lung injury } \\
\text { model }\end{array}$ & BALB/c mice & [70] \\
\hline & \multirow{6}{*}{ Linalool } & $\begin{array}{l}\text { The production of LPS-induced TNF- } \alpha \text { and } \\
\text { IL- } 6 \downarrow\end{array}$ & LPS-stimulation & Raw 264.7 cell line & [71] \\
\hline & & LPS-induced TNF- $\alpha$, IL- $1 \beta$, NO, and PGE2 $\downarrow$ & LPS-stimulated microglia cells. & Murine BV2 cell line & [72] \\
\hline & & $\begin{array}{l}\text { The levels of the pro-inflammatory markers } \\
\text { p38 MAPK, NOS2, COX2 and IL-1 } \beta \downarrow\end{array}$ & $\begin{array}{l}\text { Triple transgenic model of Alzheimer's } \\
\text { disease mice }\end{array}$ & 3xTg-AD mice & [73] \\
\hline & & $\begin{array}{c}\text { Endotoxin-induced levels of peripheral } \\
\text { nitrate/nitrite, IL- } 1 \beta, \text { IL-18, TNF- } \alpha \text {, IFN- } \gamma \text {, and } \\
\text { HMGB- } 1 \downarrow \\
\text { Nitrate/nitrite, IL- } 1 \beta, \text { TNF- } \alpha \text {, and IFN- } \gamma \text { in } \\
\text { spleen and MLNs } \downarrow\end{array}$ & Endotoxin-injection & C57BL/6J mice & [74] \\
\hline & & $\begin{array}{c}\text { Microgliosis and decreased COX2, IL- } 1 \beta \text { and } \\
\text { Nrf2 markers in the cerebral cortex and } \\
\text { hippocampus } \downarrow\end{array}$ & Focal ischemia & Wistar rats & [75] \\
\hline & & $\begin{array}{l}\text { Levels of iNOS expression in the lung tissues } \\
\text { caused by OVA exposure } \downarrow\end{array}$ & $\begin{array}{l}\text { Experimental model of airways allergic } \\
\text { inflammation }\end{array}$ & OVA-challenged mice & [76] \\
\hline
\end{tabular}


Table 2. Cont

\begin{tabular}{|c|c|c|c|c|c|}
\hline $\begin{array}{l}\text { Related Inflammatory } \\
\text { Activities }\end{array}$ & Name & Mechanism of Action & Experimental Protocol & Animal Tested & Ref \\
\hline \multirow{10}{*}{$\begin{array}{l}\text { Pro-inflammatory } \\
\text { mediator }\end{array}$} & Bornyl acetate & $\begin{array}{l}\text { IL-1 } \beta \text {-mediated up-regulation of IL-6, IL-8, } \\
\text { MMP-1, and MMP-13 } \downarrow\end{array}$ & In vitro treatment & Human chondrocytes & [77] \\
\hline & Humulene & $\begin{array}{c}\text { IL-5, CCL11 and leukotriene B4 levels in } \\
\text { bronchoalveolar lavage fluid } \downarrow \\
\text { IL-5 production in mediastinal lymph nodes } \\
\text { (In vitro assay) } \downarrow\end{array}$ & $\begin{array}{c}\text { Experimental model of airways allergic } \\
\text { inflammation }\end{array}$ & OVA-challenged mice & [78] \\
\hline & \multirow{8}{*}{$\beta$-Caryophyllene } & $\begin{array}{l}\text { The serum level of IL- } 6 \text { protein as well as the } \\
\text { level of IL- } 6 \text { mRNA in the tissue } \downarrow\end{array}$ & Dextran sulfate sodium-induced colitis & BALB/c mice & [79] \\
\hline & & $\begin{array}{c}\text { Anti-inflammatory (IL-10, Arg-1, and urea) } \\
\text { and anti-oxidant GSH parameters } \uparrow \text { and the } \\
\text { inflammatory (IL-1 } \beta \text {, TNF- } \alpha, \text { PGE2, iNOS and } \\
\text { NO) and ROS biomarkers } \downarrow\end{array}$ & LPS-stimulation & $\begin{array}{l}\text { Primary microglia cell lines } \\
\text { (C57BL/6) }\end{array}$ & [80] \\
\hline & & The elevated TNF- $\alpha$, NF- $k B$, and iNOS $\downarrow$ & $\begin{array}{l}\text { Rats fed a high fat/fructose diet to induce } \\
\text { insulin resistance and obesity }\end{array}$ & Wistar rats & [81] \\
\hline & & The iNOS in the lumbar spinal cord $\downarrow$ & $\begin{array}{l}\text { Experimental autoimmune } \\
\text { encephalomyelitis, a murine model of } \\
\text { multiple sclerosis }\end{array}$ & C57BL/6 mice & [82] \\
\hline & & $\begin{array}{l}\text { Pro-inflammatory cytokines and inflammatory } \\
\text { mediators } \\
\text { such as COX-2 and iNOS } \downarrow\end{array}$ & $\begin{array}{l}\text { Rotenone-treated rat model of Parkinson } \\
\text { disease }\end{array}$ & Wistar rats & [83] \\
\hline & & $\begin{array}{l}\text { Hypoxia-induced cytotoxicity as well as IL-1 } \beta \text {, } \\
\text { TNF- } \alpha \text { and IL- } 6 \downarrow\end{array}$ & Hypoxia exposure & Murine BV2 cell line & [84] \\
\hline & & TNF- $\alpha$ and IL- $1 \beta \downarrow$ & $\begin{array}{l}\text { Kainic acid-induced seizure activity and } \\
\text { oxidative stress }\end{array}$ & Mouse model & [85] \\
\hline & & $\begin{array}{l}\text { NO and PGE2 production } \downarrow \text { iNOS and COX- } 2 \downarrow \\
\text { Secretion of pro-inflammatory cytokines } \downarrow\end{array}$ & $\mathrm{A} \beta$-treated microglia & Murine BV2 cell line & [86] \\
\hline
\end{tabular}


Table 2. Cont

\begin{tabular}{|c|c|c|c|c|c|}
\hline $\begin{array}{l}\text { Related Inflammatory } \\
\text { Activities }\end{array}$ & Name & Mechanism of Action & Experimental Protocol & Animal Tested & Ref \\
\hline \multirow{11}{*}{ Transcription factors } & $\alpha$-Pinene & NF-KB $\downarrow$ & LPS-stimulation & $\begin{array}{l}\text { Mouse peritoneal } \\
\text { macrophages }\end{array}$ & [87] \\
\hline & \multirow{3}{*}{ d-Limonene } & \multirow{3}{*}{ NF-kB $\downarrow$} & LPS-induced acute lung injury & BALB/c mice & [88] \\
\hline & & & $\begin{array}{l}\text { Doxorubicin-induced inflammation in } \\
\text { kidneys }\end{array}$ & Wistar rats & [47] \\
\hline & & & In vitro treatment & Human chondrocytes & [49] \\
\hline & Myrcene & NF-kB $\downarrow$ & In vitro treatment & Human chondrocytes & [49] \\
\hline & \multirow{5}{*}{ 1,8-Cineole } & 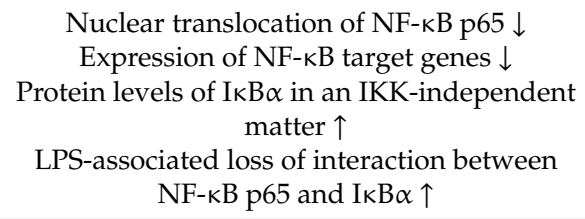 & LPS-stimulation & $\begin{array}{l}\text { U373 and HeLa } \\
\text { cell lines }\end{array}$ & [89] \\
\hline & & \multirow{4}{*}{ The expression of NF-kB p65 $\downarrow$} & $\begin{array}{l}\text { Mouse LPS-induced acute lung injury } \\
\text { model }\end{array}$ & ICR mice & [57] \\
\hline & & & $\begin{array}{c}\begin{array}{c}\text { LPS-induced acute lung injury mouse } \\
\text { model }\end{array} \\
\end{array}$ & BALB/C mice & [59] \\
\hline & & & Short-term cigarette smoke (CS) exposure & C57BL/6 mice & [61] \\
\hline & & & Mice infected with influenza A virus & BALB/C mice & [62] \\
\hline & Camphor & $\begin{array}{l}\text { The expressions of renal, testicular, hepatic } \\
\text { and pulmonary NF-kB } \uparrow\end{array}$ & An acute administration in male & Wistar rats & [90] \\
\hline
\end{tabular}


Table 2. Cont

\begin{tabular}{|c|c|c|c|c|c|}
\hline $\begin{array}{l}\text { Related Inflammatory } \\
\text { Activities }\end{array}$ & Name & Mechanism of Action & Experimental Protocol & Animal Tested & Ref. \\
\hline \multirow{9}{*}{ Transcription factors } & Borneol & Phosphorylation of NF- $\kappa$ B and IкBa $\downarrow$ & $\begin{array}{c}\text { Mouse LPS-induced acute lung } \\
\text { injury model }\end{array}$ & $\begin{array}{l}\text { Raw } 264.7 \text { cell line } \\
\text { BALB/c mice }\end{array}$ & [66] \\
\hline & \multirow{5}{*}{ Linalool } & Nuclear Nrf-2 protein translocation $\uparrow$ & $\begin{array}{l}\text { Pneumonia model infected by } \\
\text { Pasteurella multocida }\end{array}$ & $\begin{array}{l}\text { A549 cell line } \\
\text { C57BL/6J mice }\end{array}$ & [91] \\
\hline & & $\begin{array}{l}\text { LPS-induced NF- } \mathrm{kB} \text { activation } \downarrow \\
\text { Nuclear translocation of Nrf2 } \uparrow\end{array}$ & LPS-stimulated microglia cells. & Murine BV2 cell line & [72] \\
\hline & & CS-induced NF-kB activation $\downarrow$ & $\begin{array}{c}\begin{array}{c}\text { Cigarette smoke -induced acute lung } \\
\text { inflammation }\end{array}\end{array}$ & C57BL/6 mice & [92] \\
\hline & & The activation of NF- $\mathrm{kB} \downarrow$ & Endotoxin-injection & C57BL/6J mice & [74] \\
\hline & & $\begin{array}{l}\text { The activation of NF- } \mathrm{kB} \text { in the lung tissues } \\
\text { caused by OVA exposure } \downarrow\end{array}$ & $\begin{array}{l}\text { Experimental model of airways allergic } \\
\text { inflammation }\end{array}$ & OVA-challenged mice & [76] \\
\hline & Humulene & The NF-kB and the AP- 1 activation $\downarrow$ & $\begin{array}{l}\text { Experimental model of airways allergic } \\
\text { inflammation }\end{array}$ & OVA-challenged mice & [78] \\
\hline & \multirow[b]{2}{*}{$\beta$-Caryophyllene } & Hypoxia-induced the activation of NF-kB $\downarrow$ & Cultured microglia under hypoxia & Murine BV2 cell line & [84] \\
\hline & & $\begin{array}{l}\text { A } \beta 1-42 \text {-induced phosphorylation and } \\
\text { degradation of I } \kappa \mathrm{B} \alpha \text {, nuclear translocation of } \\
\text { p65, and NF- } \mathrm{B} \text { transcriptional activity } \downarrow\end{array}$ & $\mathrm{A} \beta$-treated microglia & Murine BV2 cell line & [86] \\
\hline \multirow{4}{*}{ Signal transduction } & $\alpha$-Pinene & ERK and JNK $\downarrow$ & LPS-stimulation & $\begin{array}{l}\text { Mouse peritoneal } \\
\text { macrophages }\end{array}$ & [87] \\
\hline & \multirow{2}{*}{ d-Limonene } & p38, JNK, ERK $\downarrow$ & LPS-induced acute lung injury & BALB/c mice & [88] \\
\hline & & p38 and JNK activation $\downarrow$ & In vitro treatment & Human chondrocytes & [49] \\
\hline & Myrcene & p38 and JNK activation $\downarrow$ & In vitro treatment & Human chondrocytes & [49] \\
\hline
\end{tabular}


Table 2. Cont

\begin{tabular}{|c|c|c|c|c|c|}
\hline $\begin{array}{l}\text { Related Inflammatory } \\
\text { Activities }\end{array}$ & Name & Mechanism of Action & Experimental Protocol & Animal Tested & Ref \\
\hline \multirow{9}{*}{ Signal transduction } & \multirow{4}{*}{ 1,8-Cineole } & Phosphorylated JNK in U373 cells $\downarrow$ & LPS-stimulation & $\begin{array}{l}\text { U373 and HeLa } \\
\text { cell lines }\end{array}$ & [89] \\
\hline & & $\begin{array}{l}\text { TREM-1, NLRP3 of the inflammasome } \downarrow \\
\text { Phosphorylation of the transcription factor } \\
\text { NF- } \mathrm{B} \text { and p38 } \downarrow \text { MKP- } 1 \text { phosphatase, a } \\
\text { negative regulator of MAPKs } \downarrow\end{array}$ & $\begin{array}{l}\text { LPS-induced the murine lung alveolar } \\
\text { macrophage inflammation model }\end{array}$ & MH-S cell line & [93] \\
\hline & & $\begin{array}{l}\text { NLRP3 inflammasome activation and } \\
\text { pro-inflammatory cytokine productions } \\
\text { induced by MSU in ankle tissues in vivo } \downarrow \\
\text { MSU-induced upregulation of TRPV1 } \\
\text { expression in ankle tissues and dorsal root } \\
\text { ganglion neurons innervating the ankle } \downarrow\end{array}$ & $\begin{array}{l}\text { A mouse model of gout arthritis was } \\
\text { established via MSU injection into the } \\
\text { ankle joint }\end{array}$ & BALB/c mice & [94] \\
\hline & & $\begin{array}{c}\text { Inflammatory cytokines (IL-1 } \beta, \text { TNF- } \alpha \text { and } \\
\text { IL-6) } \downarrow\end{array}$ & LPS-induced pulmonary inflammation & C57BL/6 & [95] \\
\hline & \multirow{4}{*}{ Borneol } & Phosphorylation of p38 and JNK $\downarrow$ & $\begin{array}{l}\text { Mouse LPS-induced acute lung injury } \\
\text { model }\end{array}$ & $\begin{array}{l}\text { Raw } 264.7 \text { cell line } \\
\text { BALB/c mice }\end{array}$ & [66] \\
\hline & & $\begin{array}{l}\text { The activation of M2 macrophages in a } \\
\text { STAT3-dependent manner } \uparrow\end{array}$ & DSS-induced colitis & Raw 264.7 cell line & [96] \\
\hline & & NF-kB and p38 signaling $\downarrow$ & LPS-stimulated microglia & C57BL/6 mice & [97] \\
\hline & & TRPA1 mediated cationic currents $\downarrow$ & In vitro treatment & $\begin{array}{c}\text { In heterologous expression } \\
\text { systems like Xenopus oocytes } \\
\text { and in neurons cultured from } \\
\text { trigeminal ganglia }\end{array}$ & [98] \\
\hline & Linalool & $\begin{array}{c}\text { Phosphorylation of IkB } \alpha \text { protein, p38, c-JNK, } \\
\text { and ERK } \downarrow\end{array}$ & LPS-stimulation & Raw 264.7 cell line & [71] \\
\hline
\end{tabular}


Table 2. Cont

\begin{tabular}{|c|c|c|c|c|c|}
\hline $\begin{array}{l}\text { Related Inflammatory } \\
\text { Activities }\end{array}$ & Name & Mechanism of Action & Experimental Protocol & Animal Tested & Ref. \\
\hline \multirow{4}{*}{ Signal transduction } & \multirow{4}{*}{$\beta$-Caryophyllene } & Functional agonist of $\mathrm{CB}(2) \mathrm{R}$ & LPS-stimulation & $\begin{array}{l}\text { CB2-expressiong } \\
\text { HL60 cell line }\end{array}$ & [99] \\
\hline & & $\begin{array}{l}\text { Activation of ERK } 1 / 2, \text { NF- } \kappa B \text {, IKB-kinase } \alpha / \beta \downarrow \\
\text { Involvement of CB2 and the PPAR } \gamma \text { pathway }\end{array}$ & DSS-induced colitis & CD1 mice & {$[100]$} \\
\hline & & $\begin{array}{l}\text { Cisplatin-induced renal inflammatory } \\
\text { response (chemokines MCP- } 1 \text { and MIP-2, } \\
\text { cytokines TNF- } \alpha \text { and IL-1 } \beta \text {, adhesion } \\
\text { molecule ICAM-1, and neutrophil and } \\
\text { macrophage infiltration) through a } \\
\text { CB(2)R-dependent pathway } \downarrow\end{array}$ & Cisplatin-induced nephropathy model & C57BL/6J & [101] \\
\hline & & $\begin{array}{l}\text { Activation of NF- } \kappa B \text { and the secretion of } \\
\text { inflammatory cytokines } \downarrow\end{array}$ & Hypoxia exposure & Murine BV2 cell line & [84] \\
\hline \multirow{7}{*}{ Oxidative stress } & $\alpha$-Pinene & $\begin{array}{l}\text { ROS formation and lipid peroxidation induced } \\
\text { by } \mathrm{H}_{2} \mathrm{O}_{2} \text {-stimulated oxidative damage } \downarrow\end{array}$ & $\mathrm{H}_{2} \mathrm{O}_{2}$-stimulated oxidative stress & U373-MG cells & [102] \\
\hline & \multirow[t]{2}{*}{ d-Limonene } & $\begin{array}{c}\text { ROS formation/ caspase-3/caspase- } 9 \\
\text { activation/p38 MAPK phosphorylation } \downarrow \\
\text { The Bcl-2/Bax ratio induced by } \\
\mathrm{H}_{2} \mathrm{O}_{2} \text {-stimulated oxidative damage } \uparrow\end{array}$ & $\mathrm{H}_{2} \mathrm{O}_{2}$-stimulated oxidative stress & $\begin{array}{l}\text { Human lens } \\
\text { epithelial cells }\end{array}$ & [103] \\
\hline & & $\begin{array}{l}\text { Catalase and peroxidase activities of cell } \\
\text { antioxidant enzymes } \uparrow\end{array}$ & $\begin{array}{l}\text { Lymphoid cell suspensions from lymph } \\
\text { nodes }\end{array}$ & $\mathrm{BALB} / \mathrm{c}$ mice & [104] \\
\hline & \multirow[b]{2}{*}{ Camphene } & $\begin{array}{l}\text { Strong antioxidant effect and high scavenging } \\
\text { activities against different free radicals }\end{array}$ & The nonenzymatic antioxidant capacity & Swiss mice & [105] \\
\hline & & $\begin{array}{l}\text { The cell viability and GSH content and } \\
\text { restored the mitochondrial membrane } \\
\text { potential } \uparrow \text { NO release and ROS generation } \downarrow\end{array}$ & $\begin{array}{l}\mathrm{t}-\mathrm{BHP} \text { stressed } \\
\text { alveolar macrophages }\end{array}$ & Wistar rats & [106] \\
\hline & Myrcene & $\begin{array}{l}\text { ROS, MMP-1, MMP-3, and IL-6, and increased } \\
\text { TGF } 1 \text { and type I procollagen secretions } \downarrow \text { The } \\
\text { phosphorylation of various MAPK-related } \\
\text { signaling molecules } \downarrow\end{array}$ & In vitro treatment & $\begin{array}{l}\text { UVB-irradiated human } \\
\text { dermal fibroblasts }\end{array}$ & [107] \\
\hline & $\alpha$-Terpinene & $\begin{array}{l}\text { The best antioxidant compounds in ABTS, } \\
\text { chelating power and DPPH assays }\end{array}$ & \multicolumn{2}{|c|}{ In vitro antioxidation assay } & [108] \\
\hline
\end{tabular}


Table 2. Cont.

\begin{tabular}{|c|c|c|c|c|c|}
\hline $\begin{array}{l}\text { Related Inflammatory } \\
\text { Activities }\end{array}$ & Name & Mechanism of Action & Experimental Protocol & Animal Tested & Ref. \\
\hline \multirow{12}{*}{ Oxidative stress } & $\gamma$-Terpinene & $\begin{array}{l}\text { The best antioxidant compounds in ABTS and } \\
\text { DPPH assays }\end{array}$ & \multicolumn{2}{|c|}{ In vitro antioxidation assay } & [108] \\
\hline & \multirow[t]{2}{*}{$\alpha$-Phellandrene } & $\begin{array}{l}\text { The intracellular oxidative stress } \\
\text { environment } \downarrow\end{array}$ & Mice leukemia & WEHI-3 cell line & [108] \\
\hline & & O2-production $\downarrow$ & LPS-stimulation & Raw 264.7 cell line & [53] \\
\hline & p-Cymene & SOD and catalase activity significantly $\uparrow$ & $\begin{array}{l}\text { Intraperitoneal treatment with } 0.05 \% \\
\text { Tween } 80\end{array}$ & Swiss mice & [109] \\
\hline & Terpinolene & O2-production $\downarrow$ & LPS-stimulation & Raw 264.7 cell line & [53] \\
\hline & 1,8-Cineole & $\begin{array}{l}\text { ROS formation and lipid peroxidation induced } \\
\text { by } \mathrm{H}_{2} \mathrm{O}_{2} \text {-stimulated oxidative damage } \downarrow\end{array}$ & $\mathrm{H}_{2} \mathrm{O}_{2}$-stimulated oxidative stress & U373-MG cells & [102] \\
\hline & Camphor & $\begin{array}{c}\text { Excessive ROS production and mitochondrial } \\
\text { impairment } \uparrow\end{array}$ & $\begin{array}{l}\text { Oxidative stress-mediated apoptotic cell } \\
\text { death }\end{array}$ & Schizosaccharomyces pombe & [110] \\
\hline & \multirow[b]{2}{*}{ Linalool } & $\begin{array}{l}\text { The best antioxidant compounds in ORAC and } \\
\text { Chelating power assay }\end{array}$ & \multicolumn{2}{|c|}{ In vitro antioxidation assay } & [108] \\
\hline & & $\begin{array}{c}\text { Oxidative stress and mitochondrial } \\
\text { dysfunction mediated by glutamate and } \\
\text { NMDA toxicity } \downarrow\end{array}$ & $\begin{array}{l}\text { Oxidative stress and } \\
\text { mitochondrial dysfunction }\end{array}$ & HT-22 cells & [111] \\
\hline & Humulene & $\mathrm{H}_{2} \mathrm{O}_{2}$-induced astrocytic cell death $\downarrow$ & Primary astrocytes from cerebral cortices & Neonatal wistar rats & [112] \\
\hline & \multirow[b]{2}{*}{$\beta$-Caryophyllene } & $\mathrm{H}_{2} \mathrm{O}_{2}$-induced astrocytic cell death $\downarrow$ & Primary astrocytes from cerebral cortices & Neonatal wistar rats & [112] \\
\hline & & $\begin{array}{l}\text { Rates of ROS production and the associated } \\
\text { respiratory activity in freshly isolated hepatic } \\
\text { mitochondria } \downarrow\end{array}$ & Development of adjuvant arthritis & Holtzman rats & [113] \\
\hline \multirow{3}{*}{ Autophagy } & \multirow{3}{*}{ d-Limonene } & $\begin{array}{c}\text { Expression of apoptosis and } \\
\text { autophagy-related genes } \uparrow\end{array}$ & In vitro and vivo treatment & $\begin{array}{c}\text { BALB/c mice } \\
\text { A549 and H1299 cell lines }\end{array}$ & [114] \\
\hline & & LC3 lipidation $\uparrow$ and clonogenic capacity $\downarrow$ & In vitro treatment & $\begin{array}{l}\text { SH-SY5Y, HepG2 and MCF7 } \\
\text { cell lines }\end{array}$ & [115] \\
\hline & & LC3 II $\uparrow$ and p62 levels $\downarrow$ & In vitro treatment & SH-SY5Y and MCF7 cell lines & [116] \\
\hline
\end{tabular}


Table 2. Cont.

\begin{tabular}{|c|c|c|c|c|c|}
\hline $\begin{array}{l}\text { Related Inflammatory } \\
\text { Activities }\end{array}$ & Name & Mechanism of Action & Experimental Protocol & Animal Tested & Ref. \\
\hline \multirow{6}{*}{ Autophagy } & \multirow[t]{2}{*}{ p-Cymene } & $\begin{array}{c}\text { Autophagolysosomes } \uparrow \text { and proliferation } \downarrow \\
\text { Anti-tumor metallodrug candidates }\end{array}$ & In vitro treatment & $\begin{array}{l}\text { A2780 ovarian and MCF7 and } \\
\text { MDAMB231 breast }\end{array}$ & [117] \\
\hline & & $\begin{array}{l}\text { Autophagy with materials containing Ru } \\
\text { complex } \uparrow\end{array}$ & In vitro treatment & B16 and B16-F10 cell lines & [118] \\
\hline & Camphor & Autophagy and apoptotic cell death $\uparrow$ & In vitro treatment & Schizosaccharomyces pombe & [119] \\
\hline & \multirow[b]{2}{*}{ Borneol and TMPP } & $\begin{array}{c}\text { LC3 II/I, pAMPK, mTOR, and ULK1 in } \\
\text { hypothalamus, and pAMPK, mTOR, ULK1, } \\
\text { Beclin1, and Bax in striatum } \uparrow\end{array}$ & \multirow[t]{2}{*}{ Surgical induction of GCIR } & \multirow[t]{2}{*}{ Sprague-Dawley rats } & {$[118]$} \\
\hline & & $\begin{array}{c}\text { Cortex autophagy by modulating pAMPK in } \\
\text { the pAMPK-mammalian target of } \\
\text { mTOR-ULK1 signaling pathway } \uparrow\end{array}$ & & & {$[120]$} \\
\hline & Borneol and Luteolin & $\begin{array}{l}\text { E1, p62, and ubiquitin levels } \downarrow \\
\text { Accumulation of toxic aggregates, cell death } \uparrow\end{array}$ & In vitro treatment & HepG2 cell line & {$[121]$} \\
\hline \multirow{7}{*}{ Other activities } & \multirow[b]{2}{*}{$\alpha$-Pinene } & $\begin{array}{l}\text { Sleep enhancing property through a direct } \\
\text { binding to GABAA BZD receptors }\end{array}$ & Pentobarbital-induced sleep & ICR and C57BL/6N mice & [122] \\
\hline & & $\begin{array}{c}\mathrm{G}_{2} / \mathrm{M}-\text { phase cell cycle arrest } \\
m i R-221 \text { expression level } \downarrow \\
\text { CDKN1B/p27-CDK1 and ATM-p53-Chk2 } \\
\text { pathways } \uparrow\end{array}$ & In vitro treatment & HepG2 cell line & {$[123]$} \\
\hline & 3-Carene & $\begin{array}{c}\text { sleep duration } \uparrow \text { and sleep latency } \downarrow \\
\text { GABAA receptor-mediated synaptic } \\
\text { responses } \uparrow\end{array}$ & Pentobarbital-induced sleep & ICR and C57BL/6N mice & [124] \\
\hline & 1,8-Cineole & Acetylcholinesterase activities $\downarrow$ & \multicolumn{2}{|c|}{ In vitro antioxidation assay } & [108] \\
\hline & Bornyl acetate & Lipoxygenase $\downarrow$ & \multicolumn{2}{|c|}{ In vitro antioxidation assay } & [108] \\
\hline & Limonene & Lipoxygenase $\downarrow$ & \multicolumn{2}{|c|}{ In vitro antioxidation assay } & [108] \\
\hline & $\beta$-Caryophyllene & $\begin{array}{c}\text { VCAM- } 1 \downarrow \text {, and restored vascular eNOS/iNOS } \\
\text { expression balance } \\
\text { PPAR- } \gamma \text { agonist }\end{array}$ & $\begin{array}{l}\text { high fat/fructose diet-induced } \\
\text { dyslipidemia and vascular inflammation }\end{array}$ & Wistar rats & [81] \\
\hline
\end{tabular}

$\downarrow$ denotes decreased activity; $\uparrow$ denotes increased activity. 


\subsection{Regulation of Pro-Inflammatory Mediators}

As shown in Table 2, the majority of anti-inflammatory functions of terpenes and terpenoids have been shown to be mediated by a decrease in the levels of pro-inflammatory mediators, such as NO, interleukins, TNF- $\alpha$, and PGE2. Several in vitro studies have used these pro-inflammatory mediators as biomarkers for evaluating the anti-inflammatory activity of terpenes. For example, when the RAW 264.7 cells, murine macrophages, were stimulated by lipopolysaccharide (LPS), the levels of pro-inflammatory mediators were significantly increased [125]. Pre-treatment with several terpenes including d-limonene, terpinolene, linalool, $\alpha$-terpineol, $\alpha$-phellandrene, and $\gamma$-terpinene, reduced LPS-induced pro-inflammatory mediator production in in vitro cultured RAW 264.7 cells $[46,50,51,53,68,71]$. In cultured chondrocytes, an in vitro model of arthritis-related inflammation [126], d-limonene and myrcene decreased NO and iNOS levels [49], while bornyl acetate elevated the expression of IL-11, which inhibits IL-1 $\beta$-mediated up-regulation of IL-6, IL-8, matrix metallopeptidases (MMP)-1, and MMP-13 [77].

The anti-inflammatory activity of terpenes is also evaluated using various in vivo inflammatory disease models. For example, $\alpha$-phellandrene, 1,8-cineole, borneol, and terpinen-4-ol inhibited the production of pro-inflammatory mediators induced by treatment with inflammatory substances, such as LPS and carrageenan, in lung injury models [52,57,59,66,70,95]. Furthermore, 1,8-cineole reduced the levels of various cytokines, such as IL- $1 \beta$, IL-4, IL-6, IL-13 and IL-17A, and TNF- $\alpha$ in bronchoalveolar lavage fluid of asthma models sensitized with ovalbumin (OVA) or house dust mite and short-term cigarette smoke exposure of mice [56,60,61]. The inhibitory effect of 1,8-cineole on the levels of PGE2 has been also shown in an ex vivo study using blood monocytes of patients with bronchial asthma [54]. Two other terpenes, linalool and humulene, also reduced the production of pro-inflammatory mediators in an asthma mouse model sensitized with OVA [76,78]. In addition, the anti-inflammatory effects of some terpenes have also been tested in experimental colitis models. For example, borneol, terpinen-4-ol, and $\beta$-caryophyllene reduced the levels of IL-1 $\beta$, IL-6, NACHT, LRR and PYD domains-containing protein 3 (NLRP3) inflammasome, in experimental colitis models induced by 2,4,6-trinitrobenzene sulfonic acid (TNBS) or dextran sulfate sodium (DSS) [64,69,79].

Based on their anti-inflammatory properties, researchers have been testing terpenes in vitro as well as in vivo to examine whether they also inhibit neuroinflammation. $\beta$-Caryophyllene has been reported to reduce inflammatory activity of BV2 microglia cells under hypoxia or after treatment with amyloid $\beta(\mathrm{A} \beta)$ peptide [84,86], while 1,8-cineole lowered the levels of NO and proinflammatory cytokines in A $\beta$-treated PC12 cells [58]. On the other hand, several studies have shown the effects of terpenes on the production of pro-inflammatory mediators during neuroinflammation in in vivo models. For example, d-limonene decreased NO levels in A $\beta 42$-expressing fly heads [48], and linalool reduced the levels of the pro-inflammatory markers p38 MAPK, NOS2, COX2 and IL-1 $\beta$ in the brain of a triple transgenic mouse model of Alzheimer's disease (3xTg-AD) [73]. Moreover, borneol attenuated the elevation of NO, the increase in iNOS enzymatic activity and the upregulation of iNOS expression in an ischemic model of oxygen-glucose deprivation followed by reperfusion [65].

\subsection{Regulation of Transcription Factors Involved in Inflammatory Responses}

As NF- $\mathrm{BB}$ is the main transcriptional factor that regulates the expression of pro-inflammatory mediators, it is frequently considered a target of anti-inflammatory molecules [127]. Consistently, a number of studies have shown that the inhibitory effects of several terpenes on the production pro-inflammatory mediators is mediated by the down-regulation of NF- $\mathrm{KB}$ expression or activity (Table 2). However, most studies have only shown that the translocation of NF- $\mathrm{B}$ into the nucleus, the phosphorylation of $\mathrm{I}-\mathrm{kB}$ and NF- $\mathrm{B}$, and the NF- $\mathrm{kB}$ expression levels were reduced by terpene treatment. These studies did not show that terpene-induced reduction of NF- $\mathrm{K}$ activity was a direct cause of inhibition of expression of pro-inflammatory mediators. Furthermore, there was little mention of how terpenes inhibit the activity of NF- $\kappa$ B. 
In addition, nuclear factor erythroid 2-related factor 2 (Nrf2), a transcription factor that is involved in cellular responses to oxidative damage and inflammation, is also regulated by several terpenes. Previous studies have shown that $\alpha$-pinene, $\beta$-caryophyllene, borneol, 1,8-cineole, and linalool up-regulated Nrf2 activity to protect cells from oxidative damage [72,128-131]. However, in the case of terpenes other than linalool, it is unclear whether the increased Nrf2 activity by these terpenes is associated with their anti-inflammatory action. In LPS-stimulated BV2 microglia cells, linalool-induced nuclear translocation of $\mathrm{Nrf2}$, and the anti-inflammatory effect of linalool was attenuated by transfection with Nrf2 siRNA [72].

\subsection{Signal Transduction and Direct Targets of Terpene Compounds}

Inflammatory responses are regulated by a variety of signaling pathways; however, surprisingly, few studies have examined the effects of terpenes on signal transduction. Mitogen-activated protein kinase MAPK signal transduction pathways, such as ERK, JNK, and p38, play an important role in inflammatory responses, and a variety of terpenes have been shown to inhibit these signaling pathways and to exert anti-inflammatory activities in various experimental models [49,66,71,87-89,97,100]. In addition, a recent study has reported that borneol induced the activation of M2 macrophages in a STAT3-dependent manner in a DSS-induced colitis model [96]. Unfortunately, little is known about how terpenes affect these signaling systems.

Interestingly, several terpenes, including borneol, camphor, 1,8-cineole, limonene, and linalool activate transient receptor potential vanilloids (TRPVs), a family of transient receptor potential cation channels [95,132-135]. As TRPVs have been strongly implicated in inflammatory responses, these channels are likely to mediate the anti-inflammatory action of some terpenes [136]. However, there are conflicting data on the role of TRPV channels in the inflammatory response [136], and to date, there is not much experimental evidence on their role in the anti-inflammatory action of terpenes. Meanwhile, $\beta$-caryophyllene is known as a functional agonist of cannabinoid type 2 receptor $(\mathrm{CB}(2) \mathrm{R})[99]$ ]. $\mathrm{CB}(2) \mathrm{R}$ is the peripheral receptor for cannabinoids, which is mainly expressed in immune tissues and has been shown to modulate immune cell functions [137]. In a DSS-induced colitis model and a cisplatin-induced nephropathy model, $\mathrm{CB}(2) \mathrm{R}$ mediated the anti-inflammatory activities of $\beta$-caryophyllene $[100,101]$. Similarly, the inhibitory effects of $\beta$-caryophyllene on the activation of NF- $\mathrm{KB}$ and the secretion of inflammatory cytokines were abolished by $\mathrm{CB}(2) \mathrm{R}$ RNA interference in cultured microglia under hypoxia, suggesting that $\mathrm{CB}(2) \mathrm{R}$ mediates anti-inflammatory responses induced by $\beta$-caryophyllene [84].

\subsection{Function of Terpene Compounds against Oxidative Stress}

Oxidative stress results from an imbalance between the production of ROS and their elimination by protective mechanisms. The excessive production of ROS causes tissue injury that may lead to the inflammatory process [42]. ROS generation occurs in two ways: it can be naturally produced within the cells and plays roles in the regulation of cell homeostasis and functions [138] or it can be produced during cell respiration in mitochondrial oxidative metabolism [139]. The main targets of oxidative stress are proteins, lipids, and DNA/RNA; modifications in these molecules may increase the chance of mutagenesis, as well as irreversible damage to cells, resulting in cell death by necrotic and apoptotic processes [140]. Terpene compounds may reduce the catalytic activity of enzymes involved in ROS generation, or may protect against oxidative damage through several mechanisms of antioxidant activity including scavenging a wide range of ROS and capacity for metal ion chelation [141,142].

Many studies have demonstrated antioxidative stress activities of volatile terpenes and terpenoids in vitro. d-Limonene is a monoterpene with powerful antioxidative properties. Apoptosis of human lens epithelial cells has been suggested as a cause of cataract. The in vitro study by Bai et al. showed that d-limonene can effectively protect the lens epithelial cells from apoptosis caused by $\mathrm{H}_{2} \mathrm{O}_{2}$-induced oxidative stress by inhibiting ROS generation, caspase-3/caspase- 9 activation, p38 MAPK phosphorylation, and by increasing the Bcl-2/Bax ratio [103], thereby suggesting its beneficial use for 
treating cataracts. Furthermore, d-limonene not only induced proliferation of normal lymphocytes by decreasing $\mathrm{H}_{2} \mathrm{O}_{2}$ levels via increased antioxidant enzymatic activities, but also protected the cells from the oxidative stress induced by exogenous $\mathrm{H}_{2} \mathrm{O}_{2}$ [104], indicating the pharmacological potential of limonene on normal lymphocytes in various diseases related to oxidative stress. Similarly, myrcene, a well-known natural anti-photoaging product, decreased the production of ROS, MMP-1, MMP-3, and IL-6, and increased transforming growth factor type 1 (TGF 1) and type I procollagen secretion in UVB-irradiated human dermal fibroblasts [107]. Furthermore, myrcene treatment dramatically reduced the phosphorylation of various MAPK-related signaling molecules, suggesting its potential application in the skincare industry owing to its protective effect on photoaging. Terpinolene and $\alpha$-phellandrene have also been shown to attenuate inflammation and oxidative stress in vitro by significantly inhibiting $\mathrm{NO}$ and superoxide production in a macrophage cell-culture-based assay [53]. In another in vitro experiment to assess antioxidant capacities, four monoterpenes, linalool, linalyl acetate, $\alpha$-terpinene, and $\gamma$-terpinene, were found to scavenge peroxyl radicals, strong oxidant nitrogen radicals, weak oxidant nitrogen radicals, and lipidic peroxyl radicals, as well as to chelate oxidant metal ions [108].

In addition to their in vitro functions, antioxidative stress activities of volatile terpenes and terpenoids have also been demonstrated in vivo. Camphene, another strong antioxidant, has been assessed for its antioxidant potential using tert-butyl hydroperoxide (t-BHP)-stressed rat alveolar macrophages [106]. Camphene increased the cell viability and glutathione (GSH) content and restored the mitochondrial membrane potential, but inhibited NO release and ROS generation. Compared to other terpenes, camphene has also been found to have high scavenging activities against different free radicals generated in vitro [104,105], suggesting its possible therapeutic role in various inflammatory diseases.

Antioxidant effects of volatile terpenes and terpenoids have also been demonstrated in brain cells in vitro as well as in vivo. $\alpha$-Pinene and 1,8-cineole have shown their potential in vitro antioxidant activities against $\mathrm{H}_{2} \mathrm{O}_{2}$-induced oxidative stress in the astrocytic U373-MG cell line by inhibiting ROS production and lipid peroxidation as well as by increasing the endogenous antioxidant status [102], suggesting the two compounds as regulators of the cellular redox balance in astrocytes. Similarly, both sesquiterpenes, humulene and $\beta$-caryophyllene, have been reported to have protective activity on cultured primary brain astrocytes against $\mathrm{H}_{2} \mathrm{O}_{2}$-induced cell death, possibly due to their accumulation in the cytosol [112]. $\beta$-Caryophyllene alone has shown to reduce the rate of ROS production and the associated respiratory activity albeit in an arthritic rat model [113]. In addition to those effects in astrocytic cells, another monoterpene linalool reduced cell death of immortalized neuronal HT-22, which is mediated by glutamate, an inducer of oxidative stress in neurons [111]. Furthermore, it was shown that linalool attenuates oxidative stress and mitochondrial dysfunction mediated by glutamate and N-methyl-D-aspartic acid (NMDA) toxicity, proposing its role as a neuroprotective agent against neurodegenerative brain diseases where oxidative stress contributes to their pathology. In the case of p-cymene, its antioxidant potential has been evaluated in the hippocampus of mice that were intraperitoneally treated with $0.05 \%$ Tween 80 [109]. p-Cymene significantly decreased lipid peroxidation and nitrite content, whereas significantly increased SOD and catalase activity, proposing its use as an in vivo antioxidant compound as well as a neuroprotective agent in the brain.

In contrast to their protective effects on oxidative stress, treatment of some terpenes may cause oxidative stress. Camphor is a monoterpene widely used in cosmetics, pharmaceutics, and the food industry. Agus et al. have demonstrated that it induces oxidative stress-mediated apoptotic cell death in a unicellular eukaryotic model, the fission yeast Schizosaccharomyces pombe [110]. In that study, camphor-induced excessive ROS production caused a dramatic increase in mortality rates due to the induction of intrinsic apoptosis revealed by mitochondrial impairment and apoptotic nuclear morphology, alerting the potential effects of camphor on apoptotic cell death. On the other hand, $\alpha$-phellandrene that is widely used in the food and perfume industry has been reported to induce cell morphological changes and apoptosis in vitro in murine leukemia WEHI-3 cells [143]. Treatment with $\alpha$-phellandrene-induced ROS production and cytochrome c release from mitochondria, subsequently 
triggering apoptosis of the tumor cells, thus suggesting its potential as an anti-tumor agent. However, interestingly, an opposite activity of $\alpha$-phellandrene on wound healing has recently been reported, as it was shown to attenuate inflammation and oxidative stress in vitro [53].

\subsection{Autophagy}

Through autophagy, cells can eliminate damaged or harmful components, thus, allowing the cells to survive when responding to multiple stressors [144]. There is increasing evidence suggesting that autophagy plays a critical role in the development and pathogenesis of inflammation and immunity response [145,146].

Limonene has been shown to strongly stimulate autophagy and to prevent tumor growth in vivo as well as in vitro [114]. The treatment of limonene accelerates LC3 lipidation, which is accomplished by targeting autophagosome formation and induction of basal autophagy via activating ERK and by not inhibiting the mTOR kinase [115]. Russo et al. demonstrated that limonene increases the levels of LC3-II, a lipidated form of LC3, and subsequently stimulates autophagy to induce cell death and decrease the viability of neuroblastoma cells [116]. Another monoterpene, camphor have also been studied about its effects on autophagy in yeast Schizosaccharomyces pombe [119]. In this study, low-dose camphor exposure activated autophagy, confirmed by increased autophagic vesicles and transcriptional upregulation of autophagy-related gene 6 (Atg6), whereas high-dose camphor exposure resulted in dramatic cell death rates. Among yeast apoptosis mediators, allograft inflammatory factor 1 (Aif1) was found to mediate camphor-induced cell death, indicating differential regulation of autophagy and apoptosis depending on the camphor dose.

Several interesting cases of terpene usage for the development of anti-tumor drug candidates related to autophagy activities have been reported. Borneol promotes autophagy by enhancing the permeability of chemicals, especially to brain [147]. In one study, Yu et al. have investigated the effect of the treatment with the combination of tetramethylpyrazine phosphate (TMPP) and borneol on the alleviation of ischemia/reperfusion (I/R) injury [148]. The combination therapy synergistically enhanced autophagy via increasing the levels of LC3-II/I, phosphorylated pAMPK and ULK1 to protect the hypothalamus and striatum against I/R-induced apoptosis. In another study, Yu et al. have examined the effect of TMPP and borneol on the I/R-induced damage in the cortex and hippocampus [120]. This combination therapy increased the levels of PAMPK and ULK1, while it decreased mTOR to switch from apoptosis to protective autophagy. On the other hand, p-cymene can be utilized to synthesize novel and efficient metal anti-tumor drugs, ruthenium complexes. These complexes displayed lack of cytotoxicity in vivo as well as in vitro, and successfully exhibited anti-proliferative capacity associated with a combined mechanism of apoptosis and autophagy $[117,118]$.

\subsection{Functions of Terpenes on Other Pathways}

Recently, many novel action mechanisms of volatile terpene compounds have been reported on their anti-inflammatory functions. For example, limonene treatment reduced methylglyoxal-triggered ER stress that induces inflammatory signaling in the murine preosteoblast cell line, in addition to its autophagic and ROS releasing activities [149]. In addition, $\alpha$-pinene was shown to induce cell cycle arrest and anti-tumor activity by controlling miR-221 [123], expending their functions on microRNA regulation. Moreover, 3 -carene as well as $\alpha$-pinene were shown to function as positive modulators for benzodiazepine (BZD)-receptors, exerting a sleep-enhancing effect upon oral administration [122,124], supporting the beneficial effects of forest bathing for patients with sleep disorders or anxiety.

Recent studies have also focused on novel mechanisms associated with the activity of volatile terpene compounds on vascular- or neuroinflammation. Peroxisome proliferator-activated receptor gamma (PPAR $\gamma$ ) is a ligand-dependent transcription factor that inhibits the expression of inflammatory cytokines and directs the differentiation of immune cells toward anti-inflammatory phenotypes [150]. Thus, natural PPAR $\gamma$ agonists found in foods may be beneficial to human health by acting as anti-inflammatory molecules. In an experiment involving diet-induced dyslipidemia and vascular 
inflammation with Wistar rats, $\beta$-caryophyllene induced the suppression of vascular inflammation via the PPAR $\gamma$ receptor, a treatment superior to pioglitazone, an approved PPAR $\gamma$ agonist [81]. As for action against neuroinflammation, Cutillas et al. demonstrated that some terpene components from Spanish marjoram suppress both lipoxygenase and acetylcholinesterase activities, among which bornyl acetate and limonene showed the highest lipoxygenase inhibition, while 1,8-cineole was the best acetylcholinesterase inhibitor [108]. 5-Lipoxygenase is a pro-inflammatory enzyme; acetylcholinesterase inhibitors were also shown to reduce the pro-inflammatory response as well as post-surgery neurodegeneration in the cortex and hippocampus [151,152]. Thus, terpene components are suggested as topics for further research into inflammatory and Alzheimer's diseases.

\section{Therapeutic Potentials of Volatile Forest Terpene and Terpenoids on Inflammatory Diseases: Respiratory Inflammation, Atopic Dermatitis, Arthritis, and Neuroinflammation}

Currently, many therapeutic chemicals have been developed to treat inflammation, some of which induce severe side effects. Thus, the search of novel anti-inflammatory agents with fewer side effects is highly appealing. Terpene products in various forms have been used as ethnomedicines for a long time due to their beneficial healthcare effects. Individual treatment with terpene compounds as well as a number of essential oils containing monoterpenes from plants have been reported to exert anti-inflammatory activities by inhibiting various proinflammatory steps, as described above, suggesting their application potential as therapeutic agents against many inflammatory diseases. In this section, we focus on therapeutic potentials of volatile terpenes and terpenoids emitted in forested areas, which have been reported so far to be associated with four inflammatory diseases; respiratory inflammation, atopic dermatitis, asthma, and neuroinflammation. According to literature search, 12 compounds among the major types of terpene compounds emitted in forested areas have been reported to be effective in the four diseases; six terpenes ( $\alpha$-pinene, $\beta$-pinene, $d$-limonene, myrcene, $\alpha$-terpinene, and $\beta$-caryophyllene) and six terpenoids ( 1,8 cineole, camphor, borneol, $\alpha$-terpineol, linalool, and bornyl acetate).

\subsection{Respiratory Inflammation}

Asthma is a chronic respiratory condition that results in inflammation and constriction of the bronchiole airways. Despite incomplete understanding, asthma has been known to be caused by a combination of complex interactions between environmental and genetic factors [153]. Environmental factors include exposure to air pollution and allergens [154], while many different genes have been implicated as risk factors for asthma [155]. Studies on six or more separate populations revealed that asthma is associated with various genes, such as CTLA4, GSTM1, IL4R, IL10, LTC4S, and SPINK5 [156], many of which are related to the immune system or inflammation. Although symptoms can be prevented by avoiding allergens and irritants, and by the use of inhaled corticosteroids, there is no cure for asthma [157].

Several studies have shown the beneficial effects of some volatile terpene compounds via the anti-inflammation response on airway inflammation in animal models of allergic asthma. In the mouse asthma model, inhalation of limonene significantly reduced the levels of various proinflammation-related molecules as well as airway fibrosis, indicating that limonene has the potential to reduce airway remodeling [158]. Further in vivo investigation using an asthmatic rat model, a novel series of $\alpha$-terpineol derivatives improved lung function as well as enhanced airway smooth muscle relaxation activity [17]. In addition, borneol and terpineol, extracted from a traditional Chinese formulation for the treatment of asthma, inhibited histamine-induced in vitro bronchoconstriction of isolated tracheal smooth muscles in guinea pigs, thus, indicating anti-asthmatic action [159].

Positive effects of volatile terpene compounds on asthma have been demonstrated in human studies as well. $\alpha$-Pinene was shown as a bronchodilator in human volunteers at low exposure levels [160], making it of value to patients with asthma. Another example is 1,8-cineole. Based on its pharmacodynamic effects proven in numerous pre-clinical studies, 1,8-cineole has been shown to have 
clinical efficacy and therapeutic benefits in inflammatory airway diseases, such as asthma and chronic obstructive pulmonary disease in a placebo-controlled, double-blind trial [161,162].

In contrast to asthma, pneumonia is a lung infection caused by bacteria, fungi, parasites, or viruses. Like asthma, pneumonia causes lung inflammation, but, at the end, it affects the alveoli at the end of the bronchiole airways. Pneumonia can cause the lungs to fill with mucus, making breathing difficult, but it is curable. A positive effect of bornyl acetate treatment on lung inflammation has been reported in a mouse model with acute lung injury [163]. To induce acute lung injury, BALB/c mice were injected intranasally with LPS. Pretreatment with bornyl acetate downregulated the levels of proinflammatory cytokines as well as the phosphorylation of various signaling molecules related to inflammation. The bornyl acetate treatment reduced the total number of cells, neutrophils, and macrophages, and reduced histologic alterations in the lung, suggesting bornyl acetate as a preventive agent for lung inflammatory diseases.

Another condition of airway inflammation is allergic rhinitis, which is a disorder of the upper airways caused by an inflammation of the nasal membranes. Asthma and allergic rhinitis often coexist, with allergic rhinitis being a major risk factor for the occurrence of asthma [164]. For the application of terpenes on allergic rhinitis the therapeutic usefulness of $\alpha$-pinene was suggested [165]. $\alpha$-pinene was administered daily to mice before intranasal OVA challenge. Pretreatment with $\alpha$-pinene caused a decrease in clinical symptoms. In addition, the levels of various proinflammatory mediators such as TNF- $\alpha$ and MIP-2, and nasal IgE declined in OVA-sensitized mice, suggesting $\alpha$-pinene as a promising anti-allergic agent for the clinical management of allergic rhinitis.

In contrast to the beneficial effects described above, adverse effects of inhaled terpene compounds on airways can also be found. Oxidation products of $\alpha$-pinene and d-limonene have been shown to cause irritation both in the upper airways and pulmonary regions in mice [166]. In addition, results from a population-based cross-sectional survey of the association between VOCs in residential indoor air and lung function in Canada revealed $\alpha$-pinene was one among 10 chemicals that were negatively associated with lung function out of 84 VOCs examined [167].

\subsection{Atopic Dermatitis}

Atopic dermatitis (AD) is a common chronic inflammatory skin disease. Genetic susceptibility plays an important role in causing atopic dermatitis, for example, defects in skin genes important for maintaining the barrier function [168]. Cytokines are another trigger of $A D$, which are involved in the negative regulation of immunopathogenesis of $\mathrm{AD}$ [169]. Mouse models for AD can be categorized into three groups, among which is NC mouse that spontaneously develops AD-like skin lesions. Several sublines of NC mice including NC/Nga, NC/Jic, and NC/Tnd, have been developed [170]. Upon topical application of $\beta$-pinene, atopic-like skin conditions in NC/Tnd mice were ameliorated [171,172]. In the atopic dermatitis mouse model induced by 2,4-dinitrochlorobenzene, as well as in an in vitro experiment with a human adult low-calcium high-temperature keratinocytes, Cinnamomum camphora leaves, whose major component is camphor, alleviated atopic dermatitis symptoms and allergic skin inflammatory responses, such as inhibition of chemokine production as well as Jak/STAT and ERK $1 / 2$ phosphorylation. The inhibitory effects of BVOCs such as borneol and myrcene on AD were also demonstrated in vitro. Borneol showed strong inhibitory effects on the human transient receptor potential cation channel, member A1 (hTRPA1), possibly due to its blocking action on TRPA1, expressed in sensory neurons, which functioned as a TRPA1 antagonist with anti-inflammatory and anti-allergic effects $[173,174]$. Myrcene ameliorates human skin aging via upregulation of MMPs production and downregulation of MAPK-related signaling molecules such as pERK, pp38, and pJNK and AP-1 [107].

However, in addition to the beneficial effects of the above volatile terpene compounds on AD, many adverse cases have also been reported. In evaluation studies using various assays, many compounds including $\alpha$-pinene, $\beta$-pinene, limonene, beta-phellandrene, and camphor, have been reported to show positive allergenicity responses causing contact dermatitis [175-177]. Despite their beneficial activities as antioxidants, some volatile terpene compounds can autoxidize rapidly to skin 
allergens on air exposure. Previous studies have shown that though limonene, linalool, caryophyllene, $\alpha$-terpinene are not allergenic themselves, they readily form allergenic compounds on air-exposure; and there were patients that showed a positive reaction to the oxidized products $[178,179]$, emphasizing the need of testing with such compounds.

\subsection{Arthritis}

Rheumatoid arthritis (RA) is a chronic inflammatory autoimmune disease that is characterized by progressive destruction of articular cartilage and bone and is difficult to treat effectively. Although genetic and environmental factors have been reported to be involved in the development of RA, the pathogenesis of RA has not yet been completely understood because of its complex and multifactorial etiology. Recently, accumulating data have shown the potential role of epigenetic mechanisms in the development of RA. Although there has been significant progress toward achieving disease remission without joint deformity with the aid of anti-rheumatic drugs and pharmacologic therapies, a considerable proportion of RA patients do not effectively respond to the current therapies and thus new drugs are urgently required [180].

One of the most common experimental models for an RA study is adjuvant-induced arthritis using rats, where a strong and generalized inflammatory response is exhibited. This animal model allows researchers to investigate the pathogenesis in the joints as well as systemically, such as modifications in liver metabolism, which share features of RA seen in patients. Among the 23 volatile terpene compounds investigated in this study, $\beta$-caryophyllene has been reported as a good candidate to treat RA. Vijayalaxmi et al. evaluated the ameliorative effect of oral administration of $\beta$-caryophyllene in rats with experimental arthritis induced by Complete Freund's adjuvant, and found that the compound significantly decreased arthritis and improved arthritis index, paw volume as well as histopathology and biochemical parameters such as anti-oxidants and serum nitrates [181]. More recently, $\beta$-caryophyllene has been found to reduce systemic inflammation in rats with adjuvant-induced arthritis and to, additionally, reduce oxidative stress in the liver and plasma of these animals without hepatotoxicity [113], suggesting $\beta$-caryophyllene as a starting point for the development of novel anti-inflammatory drugs.

In contrast to RA, osteoarthritis $(\mathrm{OA})$ is a degenerative disorder including mild inflammation. Rufino et al. demonstrated the anti-inflammatory and chondroprotective effect of $\alpha$-pinene in human chondrocyte, in which $\alpha$-pinene prevented against IL-1 $\beta$-stimulated inflammatory and catabolic pathways, such as NF- $\mathrm{KB}$ and JNK activation and the expression of the inflammatory (iNOS) and catabolic (MMP-1 and -13) genes [182] this suggests potential value as an anti-osteoarthritic drug. In addition, Bornyl acetate is the main volatile constituent in some Chinese traditional herbs, and Yang et al. reported its therapeutic potential in patients with OA [77]. In the study, they found that bornyl acetate elevates the expression of IL-11 in chondrocytes, and functions antagonistically on IL-1 $\beta$-mediated up-regulation of IL-6, IL-8, MMP-1, and MMP-13, which play a pivotal role in OA cartilage destruction.

\subsection{Neuroinflammation}

Neuroinflammation is inflammation in the nervous tissue and is mainly mediated by microglia, the resident mononuclear phagocytes of the brain [183]. Activation by various pro-inflammatory cues, including invading pathogens, trauma, infection, and stroke, triggers neuroinflammatory responses including activation of microglia, local invasion of circulating immune cells, and production of inflammatory factors [184]. Expression of receptors for sensing potential threats and microglial pro-inflammatory cytokines, as well as production of ROS and NO, are increased in the activated microglia [185]. Although an acute inflammatory response is beneficial to neurons, chronic inflammation damages the brain; therefore, abnormal activation of neuroinflammatory processes has been implicated in neurodegenerative diseases and brain injuries [183]. 
Coincident with their anti-inflammatory activity in the peripheral macrophages, some terpenes have been shown to inhibit the activation of microglia under several pro-inflammatory cues in in vitro studies (Table 2). For example, $\beta$-caryophyllene inhibited release of pro-inflammatory cytokines and production of NO and PGE2 as well as the activation of NF- $\mathrm{KB}$ in the cultured microglia cells under hypoxia or $\mathrm{A} \beta$-treatment $[84,86]$. Anti-neuroinflammatory activity of linalool, $\beta$-caryophyllene and borneol was also observed in the LPS-stimulated microglia cells $[72,80,97]$. On the other hand, eucalyptol and borneol have shown to exert their inhibitory effects on the pro-inflammatory responses in A $\beta$-treated PC12 cells and rat primary cultured cortical neurons with oxygen-glucose deprivation, respectively [58,65]. Based on the fact that $\beta$-caryophyllene is a ligand of CB2R that is closely related with neuroinflammation [186], most in vivo studies focused on the effect of $\beta$-caryophyllene on neuroinflammation. $\beta$-Caryophyllene inhibited neuroinflammation and showed beneficial effects in models of insulin resistance and obesity, Parkinson's disease, and multiple sclerosis [82,83,187]. Additionally, borneol attenuated brain neuronal and microglial inflammation in LPS-induced sepsis mice [97], and d-limonene reduced glial cell number and NO levels in the brain of Drosophila model of Alzheimer's disease [48].

Despite their anti-inflammatory activity in the peripheral macrophages, only a limited number of studies have shown the suppressive function of some volatile terpenes and terpenoids against neuroinflammation. However, given that many studies showed the neuroprotective properties of these compounds [14], more terpenes are expected to have neuroinflammatory activity. Therefore, further research is required in the future.

\section{Conclusions}

There has been an increase in the search of terpenes with anti-inflammatory activity in recent years. As summarized in this review, the mechanisms involved in the anti-inflammatory effects of the terpenes contained in BVOCs emitted in forests cover a wide range of targets such as transcription factors and inflammatory mediators. Although the mechanism of action of many terpenes remains to be studied, the molecular targets of terpenes are highly desirable for finding target-specific anti-inflammatory drugs. The combination of terpenes with high anti-inflammatory activity and with studied mechanisms of action, with currently used drugs could be another strategy to combat inflammatory diseases.

As more terpenoid-based clinical drugs will become available, they will play a more significant role in human disease treatment in the near future. However, some adverse effects of terpenes have been reported, depending on the concentrations of the compounds tested. For example, among the compounds described in this review, cytotoxic effects have been demonstrated for $\alpha$-pinene and camphor $[63,188,189]$. According to the Food and Drug Administration, camphor-containing products cannot exceed $11 \%$ camphor. In addition, allergic contact dermatitis has been reported following the use of $\alpha$-pinene, $\beta$-pinene, and myrcene $[175,177,178,190]$. This issue draws attention on the need to further explore the safe concentrations of terpenes for therapeutic proposes [191]. In this context, contact of BVOCs during forest bathing may be safer, albeit less beneficial compared to direct intake or application on skin. Taken together, this review highlights the use of the beneficial terpenes and terpenoids from forests for the management of various inflammatory-related diseases.

Author Contributions: Collected and analyzed the data, T.K., B.S., K.S.C., and I.-S.L.; designed the study and wrote the manuscript, K.S.C. and I.-S.L. All authors have read and agree to the published version of the manuscript.

Funding: This research was supported by two Science Research Programs of the National Research Foundation of Korea (NRF), funded by the Ministry of Education (NRF-2018R1D1A1B07050206 to I.-S.L.) and by the Ministry of Science and ICT (NRF-2017M3C1B6070572 to K.S. and I.-S.L.).

Conflicts of Interest: The authors declare no conflict of interest. 


\section{Abbreviations}

$\begin{array}{ll}\text { AD } & \text { atopic dermatitis } \\ \text { Aif1 } & \text { allograft inflammatory factor 1 } \\ \text { A } \beta & \text { amyloid } \beta \\ \text { BVOCs } & \text { biogenic volatile organic compounds } \\ \text { BZD } & \text { benzodiazepine } \\ \text { CB(2)R } & \text { cannabinoid type 2 receptor } \\ \text { COX-2 } & \text { cyclooxygenase-2 } \\ \text { DSS } & \text { dextran sulfate sodium } \\ \text { ER } & \text { endoplasmic reticulum } \\ \text { ERK } & \text { extracellular signal-regulated kinase } \\ \text { GSH } & \text { glutathione } \\ \text { hTRPA1 } & \text { human transient receptor potential cation channel, member A1 } \\ \text { I/R } & \text { ischemia/reperfusion } \\ \text { IL-1 } \beta & \text { interleukin-1 } \beta \\ \text { IL-6 } & \text { interleukin-6 } \\ \text { iNOS } & \text { inducible NO synthase } \\ \text { JNK } & \text { c-jun N-terminal kinase } \\ \text { LPS } & \text { lipopolysaccharide } \\ \text { MAPK } & \text { mitogen-activated protein kinase } \\ \text { MMP-1 } & \text { matrix metallopeptidase-1 } \\ \text { NF- } \text { B } & \text { nuclear factor-KB } \\ \text { NLRP3 } & \text { NACHT, LRR and PYD domains-containing protein 3 } \\ \text { NMDA } & \text { N-methyl-D-aspartic acid } \\ \text { NO } & \text { nitric oxide } \\ \text { Nrf2 } & \text { nuclear factor erythroid 2-related factor 2 } \\ \text { OA } & \text { osteoarthritis } \\ \text { OVA } & \text { ovalbumin } \\ \text { PGE-2 } & \text { prostaglandin E2 } \\ \text { PPAR } \gamma & \text { peroxisome proliferator activated receptor gamma } \\ \text { RA } & \text { rheumatoid arthritis } \\ \text { ROS } & \text { reactive oxygen species } \\ \text { t-BHP } & \text { tert-butyl hydroperoxide } \\ \text { TGF 1 } & \text { transforming growth factor type 1 } \\ \text { TLRs } & \text { toll-like receptors } \\ \text { TMPP } & \text { tetramethylpyrazine phosphate } \\ \text { TNBS } & \text { 2,4,6-trinitrobenzene sulfonic acid } \\ \text { TNF- } \alpha & \text { tumor necrosis factor-alpha } \\ \text { TRPVs } & \end{array}$

\section{References}

1. Gershenzon, J.; Dudareva, N. The function of terpene natural products in the natural world. Nat. Chem. Biol. 2007, 3, 408-414. [CrossRef] [PubMed]

2. Zulak, K.G.; Bohlmann, J. Terpenoid biosynthesis and specialized vascular cells of conifer defense. J. Integr. Plant Biol. 2010, 52, 86-97. [CrossRef]

3. Unsicker, S.B.; Kunert, G.; Gershenzon, J. Protective perfumes: The role of vegetative volatiles in plant defense against herbivores. Curr. Opin. Plant Biol. 2009, 12, 479-485. [CrossRef]

4. Heil, M. Indirect defence via tritrophic interactions. N. Phytol. 2008, 178, 41-61. [CrossRef]

5. Martin, D.; Rojo, A.I.; Salinas, M.; Diaz, R.; Gallardo, G.; Alam, J.; de Galarreta, C.M.R.; Cuadrado, A. Regulation of heme oxygenase-1 expression through the phosphatidylinositol 3-kinase/Akt pathway and the Nrf2 transcription factor in response to the antioxidant phytochemical carnosol. J. Biol. Chem. 2004, 279, 8919-8929. [CrossRef] 
6. Pichersky, E.; Sharkey, T.D.; Gershenzon, J. Plant volatiles: A lack of function or a lack of knowledge? Trends Plant Sci. 2006, 11, 421. [CrossRef]

7. Dicke, M.; van Loon, J. Multitrophic effects of herbivore-induced plant volatiles in an evolutionary context. Entomol. Exp. Appl. 2000, 97, 237-249. [CrossRef]

8. Guimarães, A.G.; Serafini, M.R.; Quintans-Júnior, L.J. Terpenes and derivatives as a new perspective for pain treatment: A patent review. Expert. Opin. Ther. Pat. 2014, 24, 243-265. [CrossRef]

9. Lange, B.M.; Ahkami, A. Metabolic engineering of plant monoterpenes, sesquiterpenes and diterpenes-Current status and future opportunities. Plant Biotechnol. J. 2013, 11, 169-196. [CrossRef]

10. Mewalal, R.; Rai, D.K.; Kainer, D.; Chen, F.; Külheim, C.; Peter, G.F.; Tuskan, G.A. Plant-derived terpenes: A feedstock for specialty biofuels. Trends Biotechnol. 2017, 35, 227-240. [CrossRef]

11. Dubey, V.S.; Bhalla, R.; Luthra, R. An overview of the non-mevalonate pathway for terpenoid biosynthesis in plants. J. Biosci. 2003, 28, 637-646. [CrossRef]

12. Kirby, J.; Keasling, J.D. Biosynthesis of plant isoprenoids: Perspectives for microbial engineering. Annu. Rev. Plant Biol. 2009, 60, 335-355. [CrossRef]

13. International Union of Pure and Applied Chemistry. Compendium of Chemical Terminology, 2nd ed.; The "Gold Book"; McNaught, A.D., Wilkinson, A., Eds.; Blackwell Scientific Publications: Oxford, UK, 1997.

14. Cho, K.S.; Lim, Y.-R.; Lee, K.; Lee, J.; Lee, J.H.; Lee, I.-S. Terpenes from forests and human health. Toxicol. Res. 2017, 33, 97-106. [CrossRef]

15. Thoppil, R.J.; Bishayee, A. Terpenoids as potential chemopreventive and therapeutic agents in liver cancer. World J. Hepatol. 2011, 3, 228-249. [CrossRef]

16. Huang, M.; Lu, J.-J.; Huang, M.-Q.; Bao, J.-L.; Chen, X.-P.; Wang, Y.-T. Terpenoids: Natural products for cancer therapy. Expert. Opin. Investig. Drugs 2012, 21, 1801-1818. [CrossRef]

17. Zhu, W.; Liu, X.; Wang, Y.; Tong, Y.; Hu, Y. Discovery of a novel series of $\alpha$-terpineol derivatives as promising anti-asthmatic agents: Their design, synthesis, and biological evaluation. Eur. J. Med. Chem. 2018, 143, 419-425. [CrossRef]

18. Guenther, A.; Hewitt, C.N.; Erickson, D.; Fall, R.; Geron, C.; Graedel, T.; Harley, P.; Klinger, L.; Lerdau, M.; Mckay, W.A.; et al. A global model of natural volatile organic compound emissions. J. Geophys. Res. Atmos. 1995, 100, 8873-8892. [CrossRef]

19. Helmig, D.; Klinger, L.F.; Guenther, A.; Vierling, L.; Geron, C.; Zimmerman, P. Biogenic volatile organic compound emissions (BVOCs). Chemosphere 1999, 38, 2163-2187. [CrossRef]

20. Fall, R. Abundant oxygenates in the atmosphere: A biochemical perspective. Chem. Rev. 2003, 103, 4941-4952. [CrossRef]

21. Bai, J.; Baker, B.; Liang, B.; Greenberg, J.; Guenther, A. Isoprene and monoterpene emissions from an Inner Mongolia grassland. Atmos. Environ. 2006, 40, 5753-5758. [CrossRef]

22. Peñuelas, J.; Staudt, M. BVOCs and global change. Trends Plant Sci. 2010, 15, 133-144. [CrossRef] [PubMed]

23. Pokorska, O.; Dewulf, J.; Amelynck, C.; Schoon, N.; Šimpraga, M.; Steppe, K.; Van Langenhove, H. Isoprene and terpenoid emissions from Abies alba: Identification and emission rates under ambient conditions. Atmos. Environ. 2012, 59, 501-508. [CrossRef]

24. Aydin, Y.M.; Yaman, B.; Koca, H.; Dasdemir, O.; Kara, M.; Altiok, H.; Dumanoglu, Y.; Bayram, A.; Tolunay, D.; Odabasi, M.; et al. Biogenic volatile organic compound (BVOC) emissions from forested areas in Turkey: Determination of specific emission rates for thirty-one tree species. Sci. Total Environ. 2014, 490, $239-253$. [CrossRef] [PubMed]

25. Holdern, M.W.; Westberg, H.H.; Zimmerman, P.R. Analysis of monoterpene hydrocarbons in rural atmospheres. J. Geophys. Res. Ocean. 1979, 84, 5083-5088. [CrossRef]

26. Warneck, P. Chemistry of the Natural Atmosphere; Academic Press: Cambridge, MA, USA, 1988; p. 242.

27. Bao, H.; Kondo, A.; Kaga, A.; Tada, M.; Sakaguti, K.; Inoue, Y.; Shimoda, Y.; Narumi, D.; Machimura, T. Biogenic volatile organic compound emission potential of forests and paddy fields in the Kinki region of Japan. Environ. Res. 2008, 106, 156-169. [CrossRef]

28. Zuo, Z.; Weraduwage, S.M.; Lantz, A.T.; Sanchez, L.M.; Weise, S.E.; Wang, J.; Childs, K.L.; Sharkey, T.D. Isoprene acts as a signaling molecule in gene networks important for stress responses and plant growth. Plant Physiol. 2019, 180, 124-152. [CrossRef] 
29. Zuo, Z.; Weraduwage, S.M.; Lantz, A.T.; Sanchez, L.M.; Weise, S.E.; Wang, J.; Childs, K.L.; Sharkey, T.D.; Fuchs, H.; Hofzumahaus, A.; et al. Experimental evidence for efficient hydroxyl radical regeneration in isoprene oxidation. Plant Physiol. 2013, 6, 1023-1026.

30. Fineschi, S.; Loreto, F.; Staudt, M.; Peñuelas, J. Diversification of volatile isoprenoid emissions from trees: Evolutionary and ecological perspectives. In Biology, Controls and Models of Tree Volatile Organic Compound Emissions; Niinemets, Ü, Monson, R.K., Eds.; Springer: Dordrecht, The Netherlands, 2013; pp. 1-20.

31. Lange, B.M. The Evolution of plant secretory structures and emergence of terpenoid chemical diversity. Annu. Rev. Plant Biol. 2015, 66, 139-159. [CrossRef]

32. Staudt, M.; Lhoutellier, L. Volatile organic compound emission from holm oak infested by gypsy moth larvae: Evidence for distinct responses in damaged and undamaged leaves. Tree Physiol. 2007, 27, 1433-1440. [CrossRef]

33. Geron, C.; Rasmussen, R.; Arnts, R.R.; Guenther, A. A review and synthesis of monoterpene speciation from forests in the United States. Atmos. Environ. 2000, 34, 1761-1781. [CrossRef]

34. Lee, J.; Cho, K.S.; Jeon, Y.; Kim, J.B.; Lim, Y.; Lee, K.; Lee, I.-S. Characteristics and distribution of terpenes in South Korean forests. J. Ecol. Environ. 2017, 41, 19. [CrossRef]

35. Noe, S.M.; Hüve, K.; Niinemets, Ü.; Copolovici, L. Seasonal variation in vertical volatile compounds air concentrations within a remote hemiboreal mixed forest. Atmos. Chem. Phys. 2012, 12, 3909-3926. [CrossRef]

36. Helmig, D.; Daly, R.W.; Milford, J.; Guenther, A. Seasonal trends of biogenic terpene emissions. Chemosphere 2013, 93, 35-46. [CrossRef] [PubMed]

37. Staudt, M.; Lhoutellier, L. Monoterpene and sesquiterpene emissions from Quercus coccifera exhibit interacting responses to light and temperature. Biogeosciences 2011, 8, 2757-2771. [CrossRef]

38. Helmig, D.; Ortega, J.; Duhl, T.; Tanner, D.; Guenther, A.; Harley, P.; Wiedinmyer, C.; Milford, J.; Sakulyanontvittaya, T. Sesquiterpene emissions from pine trees-identifications, emission rates and flux estimates for the contiguous United States. Environ. Sci. Technol. 2007, 41, 1545-1553. [CrossRef] [PubMed]

39. Liu, T.; Zhang, L.; Joo, D.; Sun, S.-C. NF-кB signaling in inflammation. Signal Transduct. Target. Ther. 2017, 2, 17023. [CrossRef]

40. Lawrence, T. The nuclear factor NF-kappaB pathway in inflammation. Cold Spring Harb. Perspect. Biol. 2009, 1, a001651. [CrossRef]

41. Kyriakis, J.M.; Avruch, J. Mammalian MAPK signal transduction pathways activated by stress and inflammation: A 10-year update. Physiol. Rev. 2012, 92, 689-737. [CrossRef]

42. Mittal, M.; Siddiqui, M.R.; Tran, K.; Reddy, S.P.; Malik, A.B. Reactive oxygen species in inflammation and tissue injury. Antioxid. Redox Signal. 2014, 20, 1126-1167. [CrossRef]

43. Warnatsch, A.; Tsourouktsoglou, T.-D.; Branzk, N.; Wang, Q.; Reincke, S.; Herbst, S.; Gutierrez, M.; Papayannopoulos, V. Reactive oxygen species localization programs inflammation to clear microbes of different size. Immunity 2017, 46, 421-432. [CrossRef]

44. Qian, M.; Fang, X.; Wang, X. Autophagy and inflammation. Clin. Transl. Med. 2017, 6, 24. [CrossRef] [PubMed]

45. Hasnain, S.Z.; Lourie, R.; Das, I.; Chen, A.C.-H.; McGuckin, M.A. The interplay between endoplasmic reticulum stress and inflammation. Immunol. Cell Biol. 2012, 90, 260-270. [CrossRef] [PubMed]

46. Yoon, W.-J.; Lee, N.H.; Hyun, C.-G. Limonene suppresses lipopolysaccharide-induced production of nitric oxide, prostaglandin $\mathrm{E}_{2}$, and pro-inflammatory cytokines in RAW 264.7 macrophages. J. Oleo Sci. 2010, 59, 415-421. [CrossRef]

47. Rehman, M.U.; Tahir, M.; Khan, A.Q.; Khan, R.; Oday-O-Hamiza; Lateef, A.; Hassan, S.K.; Rashid, S.; Ali, N.; Zeeshan, M.; et al. d-limonene suppresses doxorubicin-induced oxidative stress and inflammation via repression of COX-2, iNOS, and NFkB in kidneys of Wistar rats. Exp. Biol. Med. 2014, 239, 465-476. [CrossRef]

48. Shin, M.; Liu, Q.F.; Choi, B.; Shin, C.; Lee, B.; Yuan, C.; Song, Y.J.; Yun, H.S.; Lee, I.-S.; Koo, B.-S.; et al. Neuroprotective effects of limonene $(+)$ against $A \beta 42$-induced neurotoxicity in a Drosophila model of Alzheimer's disease. Biol. Pharm. Bull. 2019, 43, 409-417. [CrossRef]

49. Rufino, A.T.; Ribeiro, M.; Sousa, C.; Judas, F.; Salgueiro, L.; Cavaleiro, C.; Mendes, A.F. Evaluation of the anti-inflammatory, anti-catabolic and pro-anabolic effects of E-caryophyllene, myrcene and limonene in a cell model of osteoarthritis. Eur. J. Pharmacol. 2015, 750, 141-150. [CrossRef] 
50. Ramalho, T.R.; de Oliveira, T.R.; de Oliveira, M.T.P.; de Araujo Lima, A.L.; Bezerra-Santos, C.R.; Piuvezam, M.R. Gamma-terpinene modulates acute inflammatory response in mice. Planta Med. 2015, 81, 1248-1254.

51. Ramalho, T.R.; Filgueiras, L.R.; de Oliveira, M.T.P.; de Araujo Lima, A.L.; Bezerra-Santos, C.R.; Jancar, S.; Piuvezam, M.R. Gamma-terpinene modulation of LPS-stimulated macrophages is dependent on the PGE2/IL-10 axis. Planta Med. 2016, 82, 1341-1345.

52. Siqueira, H.D.S.; Neto, B.S.; Sousa, D.P.; Gomes, B.S.; da Silva, F.V.; Cunha, F.V.M.; Wanderley, C.W.S.; Pinheiro, G.; Cândido, A.G.F.; Wong, D.V.T.; et al. $\alpha$ phellandrene, a cyclic monoterpene, attenuates inflammatory response through neutrophil migration inhibition and mast cell degranulation. Life Sci. 2016, 160, 27-33. [CrossRef]

53. De Christo Scherer, M.M.; Marques, F.M.; Figueira, M.M.; Peisino, M.C.O.; Schmitt, E.F.P.; Kondratyuk, T.P.; Endringer, D.C.; Scherer, R.; Fronza, M. Wound healing activity of terpinolene and $\alpha$-phellandrene by attenuating inflammation and oxidative stress in vitro. J. Tissue Viability 2019, 28, 94-99. [CrossRef]

54. Juergens, U.R.; Stober, M.; Schmidt-Schilling, L.; Kleuver, T.; Vetter, H. Antiinflammatory effects of euclyptol (1.8-cineole) in bronchial asthma: Inhibition of arachidonic acid metabolism in human blood monocytes ex vivo. Eur. J. Med. Res. 1998, 3, 407-412. [PubMed]

55. Juergens, U.R.; Stober, M.; Vetter, H. Inhibition of cytokine production and arachidonic acid metabolism by eucalyptol (1.8-cineole) in human blood monocytes in vitro. Eur. J. Med. Res. 1998, 3, 508-510. [PubMed]

56. Bastos, V.P.D.; Gomes, A.S.; Lima, F.J.B.; Brito, T.S.; Soares, P.M.G.; Pinho, J.P.M.; Silva, C.S.; Santos, A.A.; Souza, M.H.L.P.; Magalhães, P.J.C. Inhaled 1,8-cineole reduces inflammatory parameters in airways of ovalbumin-challenged guinea pigs. Basic Clin. Pharmacol. Toxicol. 2011, 108, 34-39. [CrossRef] [PubMed]

57. Zhao, C.; Sun, J.; Fang, C.; Tang, F. 1,8-cineol attenuates LPS-induced acute pulmonary inflammation in ice. Inflammation 2014, 37, 566-572. [CrossRef] [PubMed]

58. Khan, A.; Vaibhav, K.; Javed, H.; Tabassum, R.; Ahmed, M.E.; Khan, M.M.; Khan, M.B.; Shrivastava, P.; Islam, F.; Siddiqui, M.S.; et al. 1,8-cineole (eucalyptol) mitigates inflammation in amyloid Beta toxicated PC12 cells: Relevance to Alzheimer's disease. Neurochem. Res. 2014, 39, 344-352. [CrossRef] [PubMed]

59. Kim, K.Y.; Lee, H.S.; Seol, G.H. Eucalyptol suppresses matrix metalloproteinase-9 expression through an extracellular signal-regulated kinase-dependent nuclear factor-kappa B pathway to exert anti-inflammatory effects in an acute lung inflammation model. J. Pharm. Pharmacol. 2015, 67, 1066-1074. [CrossRef] [PubMed]

60. Lee, H.-S.; Park, D.-E.; Song, W.-J.; Park, H.-W.; Kang, H.-R.; Cho, S.-H.; Sohn, S.-W. Effect of 1.8-cineole in Dermatophagoides pteronyssinus-Stimulated bronchial epithelial cells and mouse model of asthma. Biol. Pharm. Bull. 2016, 39, 946-952. [CrossRef]

61. Kennedy-Feitosa, E.; Okuro, R.T.; Pinho Ribeiro, V.; Lanzetti, M.; Barroso, M.V.; Zin, W.A.; Porto, L.C.; Brito-Gitirana, L.; Valenca, S.S. Eucalyptol attenuates cigarette smoke-induced acute lung inflammation and oxidative stress in the mouse. Pulm. Pharmacol. Ther. 2016, 41, 11-18. [CrossRef]

62. Li, Y.; Lai, Y.; Wang, Y.; Liu, N.; Zhang, F.; Xu, P. 1, 8-cineol protect against influenza-virus-induced pneumonia in mice. Inflammation 2016, 39, 1582-1593. [CrossRef]

63. Somade, O.T.; Ajayi, B.O.; Safiriyu, O.A.; Oyabunmi, O.S.; Akamo, A.J. Renal and testicular up-regulation of pro-inflammatory chemokines (RANTES and CCL2) and cytokines (TNF- $\alpha$, IL-1 $\beta$, IL-6) following acute edible camphor administration is through activation of NF-kB in rats. Toxicol. Rep. 2019, 6, 759-767. [CrossRef]

64. Juhas, S.; Cikos, S.; Czikkova, S.; Vesela, J.; Il'kova, G.; Hajek, T.; Domaracka, K.; Domaracky, M.; Bujnakova, D.; Rehak, P.; et al. Effects of borneol and thymoquinone on TNBS-induced colitis in mice. Folia Biol. (Praha). 2008, 54, 1-7. [PubMed]

65. Liu, R.; Zhang, L.; Lan, X.; Li, L.; Zhang, T.-T.; Sun, J.-H.; Du, G.-H. Protection by borneol on cortical neurons against oxygen-glucose deprivation/reperfusion: Involvement of anti-oxidation and anti-inflammation through nuclear transcription factor карpaB signaling pathway. Neuroscience 2011, 176, 408-419. [CrossRef] [PubMed]

66. Zhong, W.; Cui, Y.; Yu, Q.; Xie, X.; Liu, Y.; Wei, M.; Ci, X.; Peng, L. Modulation of LPS-stimulated pulmonary inflammation by borneol in murine acute lung injury model. Inflammation 2014, 37, 1148-1157. [CrossRef] [PubMed]

67. Wang, B.; Chen, T.; Xue, L.; Wang, J.; Jia, Y.; Li, G.; Ren, H.; Wu, F.; Wu, M.; Chen, Y. Methamphetamine exacerbates neuroinflammatory response to lipopolysaccharide by activating dopamine D1-like receptors. Int. Immunopharmacol. 2019, 73, 1-9. [CrossRef] 
68. De Oliveira, M.G.B.; Marques, R.B.; de Santana, M.F.; Santos, A.B.D.; Brito, F.A.; Barreto, E.O.; De Sousa, D.P.; Almeida, F.R.C.; Badauê-Passos, D., Jr.; Antoniolli, Â.R.; et al. $\alpha$-terpineol reduces mechanical hypernociception and inflammatory response. Basic Clin. Pharmacol. Toxicol. 2012, 111, 120-125. [CrossRef]

69. Zhang, Z.; Shen, P.; Lu, X.; Li, Y.; Liu, J.; Liu, B.; Fu, Y.; Cao, Y.; Zhang, N. In Vivo and In Vitro Study on the efficacy of terpinen-4-ol in dextran sulfate sodium-induced mice experimental colitis. Front. Immunol. 2017, 8, 558. [CrossRef]

70. Ning, J.; Xu, L.; Zhao, Q.; Zhang, Y.; Shen, C. The protective effects of terpinen-4-ol on LPS-induced acute lung injury via activating PPAR- $\gamma$. Inflammation 2018, 41, 2012-2017. [CrossRef]

71. Huo, M.; Cui, X.; Xue, J.; Chi, G.; Gao, R.; Deng, X.; Guan, S.; Wei, J.; Soromou, L.W.; Feng, H.; et al. Anti-inflammatory effects of linalool in RAW 264.7 macrophages and lipopolysaccharide-induced lung injury model. J. Surg. Res. 2013, 180, e47-e54. [CrossRef]

72. Li, Y.; Lv, O.; Zhou, F.; Li, Q.; Wu, Z.; Zheng, Y. Linalool inhibits LPS-induced inflammation in BV2 microglia cells by activating Nrf2. Neurochem. Res. 2015, 40, 1520-1525. [CrossRef]

73. Sabogal-Guáqueta, A.M.; Osorio, E.; Cardona-Gómez, G.P. Linalool reverses neuropathological and behavioral impairments in old triple transgenic Alzheimer's mice. Neuropharmacol. 2016, 102, 111-120. [CrossRef]

74. Lee, S.-C.; Wang, S.-Y.; Li, C.-C.; Liu, C.-T. Anti-inflammatory effect of cinnamaldehyde and linalool from the leaf essential oil of Cinnamomum osmophloeum Kanehira in endotoxin-induced mice. J. Food Drug Anal. 2018, 26, 211-220. [CrossRef] [PubMed]

75. Barrera-Sandoval, A.M.; Osorio, E.; Cardona-Gómez, G.P. Microglial-targeting induced by intranasal linalool during neurological protection postischemia. Eur. J. Pharmacol. 2019, 857, 172420. [CrossRef] [PubMed]

76. Kim, M.-G.; Kim, S.-M.; Min, J.-H.; Kwon, O.-K.; Park, M.-H.; Park, J.-W.; Ahn, H.I.; Hwang, J.-Y.; Oh, S.-R.; Lee, J.-W.; et al. Anti-inflammatory effects of linalool on ovalbumin-induced pulmonary inflammation. Int. Immunopharmacol. 2019, 74, 105706. [CrossRef] [PubMed]

77. Yang, H.; Zhao, R.; Chen, H.; Jia, P.; Bao, L.; Tang, H. Bornyl acetate has an anti-inflammatory effect in human chondrocytes via induction of IL-11. IUBMB Life 2014, 66, 854-859. [CrossRef]

78. Rogerio, A.P.; Andrade, E.L.; Leite, D.F.P.; Figueiredo, C.P.; Calixto, J.B. Preventive and therapeutic anti-inflammatory properties of the sesquiterpene alpha-humulene in experimental airways allergic inflammation. Br. J. Pharmacol. 2009, 158, 1074-1087. [CrossRef]

79. Cho, J.Y.; Chang, H.-J.; Lee, S.-K.; Kim, H.-J.; Hwang, J.-K.; Chun, H.S. Amelioration of dextran sulfate sodium-induced colitis in mice by oral administration of $\beta$-caryophyllene, a sesquiterpene. Life Sci. 2007, 80, 932-939. [CrossRef]

80. Askari, V.R.; Shafiee-Nick, R. The protective effects of $\beta$-caryophyllene on LPS-induced primary microglia M1/M2 imbalance: A mechanistic evaluation. Life Sci. 2019, 219, 40-73. [CrossRef]

81. Youssef, D.A.; El-Fayoumi, H.M.; Mahmoud, M.F. Beta-caryophyllene protects against diet-induced dyslipidemia and vascular inflammation in rats: Involvement of CB2 and PPAR- $\gamma$ receptors. Chem. Biol. Interact. 2019, 297, 16-24. [CrossRef]

82. Alberti, T.B.; Barbosa, W.L.R.; Vieira, J.L.F.; Raposo, N.R.B.; Dutra, R.C. (-)- $\beta$-caryophyllene, a CB2 receptor-selective phytocannabinoid, suppresses motor paralysis and neuroinflammation in a murine model of multiple sclerosis. Int. J. Mol. Sci. 2017, 18, 691. [CrossRef]

83. Ojha, S.; Javed, H.; Azimullah, S.; Haque, M.E. $\beta$-Caryophyllene, a phytocannabinoid attenuates oxidative stress, neuroinflammation, glial activation, and salvages dopaminergic neurons in a rat model of Parkinson disease. Mol. Cell. Biochem. 2016, 418, 59-70. [CrossRef]

84. Guo, K.; Mou, X.; Huang, J.; Xiong, N.; Li, H. Trans-caryophyllene suppresses hypoxia-induced neuroinflammatory responses by inhibiting NF-kB activation in microglia. J. Mol. Neurosci. 2014, 54, 41-48. [CrossRef]

85. Liu, H.; Song, Z.; Liao, D.; Zhang, T.; Liu, F.; Zhuang, K.; Luo, K.; Yang, L. Neuroprotective effects of trans-caryophyllene against kainic acid induced seizure activity and oxidative stress in mice. Neurochem. Res. 2015, 40, 118-123. [CrossRef] [PubMed]

86. Hu, Y.; Zeng, Z.; Wang, B.; Guo, S. Trans-caryophyllene inhibits amyloid $\beta$ (A $\beta$ ) oligomer-induced neuroinflammation in BV-2 microglial cells. Int. Immunopharmacol. 2017, 51, 91-98. [CrossRef] [PubMed] 
87. Kim, D.-S.; Lee, H.-J.; Jeon, Y.-D.; Han, Y.-H.; Kee, J.-Y.; Kim, H.-J.; Shin, H.-J.; Kang, J.; Lee, B.S.; Kim, S.-H.; et al. Alpha-pinene exhibits anti-inflammatory activity through the suppression of MAPKs and the NF- $\mathrm{kB}$ pathway in mouse peritoneal macrophages. Am. J. Chin. Med. 2015, 43, 731-742. [CrossRef] [PubMed]

88. Chi, G.; Wei, M.; Xie, X.; Soromou, L.W.; Liu, F.; Zhao, S. Suppression of MAPK and NF-kB pathways by Limonene contributes to attenuation of lipopolysaccharide-induced inflammatory responses in acute lung injury. Inflammation 2013, 36, 501-511. [CrossRef] [PubMed]

89. Greiner, J.F.-W.; Müller, J.; Zeuner, M.-T.; Hauser, S.; Seidel, T.; Klenke, C.; Grunwald, L.-M.; Schomann, T.; Widera, D.; Sudhoff, H.; et al. 1,8-cineol inhibits nuclear translocation of NF-kB p65 and NF-kB-dependent transcriptional activity. Biochim. Biophys. Acta Mol. Cell Res. 2013, 1833, 2866-2878. [CrossRef]

90. Somade, O.T.; Ajayi, B.O.; Tajudeen, N.O.; Atunlute, E.M.; James, A.S.; Kehinde, S.A. Camphor elicits up-regulation of hepatic and pulmonary pro-inflammatory cytokines and chemokines via activation of NF-kB in rats. Pathophysiology 2019, 26, 305-313. [CrossRef]

91. Wu, Q.; Yu, L.; Qiu, J.; Shen, B.; Wang, D.; Soromou, L.W.; Feng, H. Linalool attenuates lung inflammation induced by Pasteurella multocida via activating Nrf-2 signaling pathway. Int. Immunopharmacol. 2014, 21, 456-463. [CrossRef]

92. Ma, J.; Xu, H.; Wu, J.; Qu, C.; Sun, F.; Xu, S. Linalool inhibits cigarette smoke-induced lung inflammation by inhibiting NF-кB activation. Int. Immunopharmacol. 2015, 29, 708-713. [CrossRef]

93. Yadav, N.; Chandra, H. Suppression of inflammatory and infection responses in lung macrophages by eucalyptus oil and its constituent 1,8-cineole: Role of pattern recognition receptors TREM-1 and NLRP3, the MAP kinase regulator MKP-1, and NFKB. PLoS ONE 2017, 12, e0188232. [CrossRef]

94. Yin, C.; Liu, B.; Wang, P.; Li, X.; Li, Y.; Zheng, X.; Tai, Y.; Wang, C.; Liu, B. Eucalyptol alleviates inflammation and pain responses in a mouse model of gout arthritis. Br. J. Pharmacol. 2019. [CrossRef]

95. Caceres, A.I.; Liu, B.; Jabba, S.V.; Achanta, S.; Morris, J.B.; Jordt, S.-E. Transient receptor potential cation channel subfamily M member 8 channels mediate the anti-inflammatory effects of eucalyptol. Br. J. Pharmacol. 2017, 174, 867-879. [CrossRef]

96. Zhang, X.; Xu, F.; Liu, L.; Feng, L.; Wu, X.; Shen, Y.; Sun, Y.; Wu, X.; Xu, Q. (+)-borneol improves the efficacy of edaravone against DSS-induced colitis by promoting M2 macrophages polarization via JAK2-STAT3 signaling pathway. Int. Immunopharmacol. 2017, 53, 1-10. [CrossRef] [PubMed]

97. Wang, L.; Liang, Q.; Lin, A.; Wu, Y.; Min, H.; Song, S.; Wang, Y.; Wang, H.; Yi, L.; Gao, Q. Borneol alleviates brain injury in sepsis mice by blocking neuronal effect of endotoxin. Life Sci. 2019, 232, 116647. [CrossRef] [PubMed]

98. Sherkheli, M.A.; Schreiner, B.; Haq, R.; Werner, M.; Hatt, H. Borneol inhibits TRPA1, a proinflammatory and noxious pain-sensing cation channel. Pak. J. Pharm. Sci. 2015, 28, 1357-1363. [PubMed]

99. Gertsch, J.; Leonti, M.; Raduner, S.; Racz, I.; Chen, J.-Z.; Xie, X.-Q.; Altmann, K.-H.; Karsak, M.; Zimmer, A. Beta-caryophyllene is a dietary cannabinoid. Proc. Natl. Acad. Sci. USA 2008, 105, 9099-9104. [CrossRef] [PubMed]

100. Bento, A.F.; Marcon, R.; Dutra, R.C.; Claudino, R.F.; Cola, M.; Leite, D.F.P.; Calixto, J.B. $\beta$-caryophyllene inhibits dextran sulfate sodium-induced colitis in mice through CB2 receptor activation and PPAR $\gamma$ pathway. Am. J. Pathol. 2011, 178, 1153-1166. [CrossRef] [PubMed]

101. Horváth, B.; Mukhopadhyay, P.; Kechrid, M.; Patel, V.; Tanchian, G.; Wink, D.A.; Gertsch, J.; Pacher, P. $\beta$-Caryophyllene ameliorates cisplatin-induced nephrotoxicity in a cannabinoid 2 receptor-dependent manner. Free Radic. Biol. Med. 2012, 52, 1325-1333. [CrossRef]

102. Porres-Martínez, M.; González-Burgos, E.; Carretero, M.E.; Gómez-Serranillos, M.P. Major selected monoterpenes $\alpha$-pinene and 1,8-cineole found in Salvia lavandulifolia (Spanish sage) essential oil as regulators of cellular redox balance. Pharm. Biol. 2015, 53, 921-929. [CrossRef]

103. Bai, J.; Zheng, Y.; Wang, G.; Liu, P. Protective effect of D-limonene against oxidative stress-induced cell damage in human lens epithelial cells via the p38 pathway. Oxid. Med. Cell. Longev. 2016, 2016, 5962832. [CrossRef]

104. Roberto, D.; Micucci, P.; Sebastian, T.; Graciela, F.; Anesini, C. Antioxidant activity of Limonene on normal murine lymphocytes: Relation to $\mathrm{H} 2 \mathrm{O} 2$ modulation and cell proliferation. Basic Clin. Pharmacol. Toxicol. 2010, 106, 38-44. [CrossRef] 
105. Quintans-Júnior, L.; Moreira, J.C.F.; Pasquali, M.A.B.; Rabie, S.M.S.; Pires, A.S.; Schröder, R.; Rabelo, T.K.; Santos, J.P.A.; Lima, P.S.S.; Cavalcanti, S.C.H.; et al. Antinociceptive activity and redox profile of the monoterpenes (+)-camphene, $p$-cymene, and geranyl acetate in experimental models. ISRN Toxicol. 2013, 2013, 459530. [CrossRef] [PubMed]

106. Tiwari, M.; Kakkar, P. Plant derived antioxidants-geraniol and camphene protect rat alveolar macrophages against t-BHP induced oxidative stress. Toxicol. Vitr. 2009, 23, 295-301. [CrossRef] [PubMed]

107. Hwang, E.; Ngo, H.T.T.; Park, B.; Seo, S.-A.; Yang, J.-E.; Yi, T.-H. Myrcene, an aromatic volatile compound, ameliorates human skin extrinsic aging via regulation of MMPs production. Am. J. Chin. Med. 2017, 45, 1113-1124. [CrossRef] [PubMed]

108. Cutillas, A.-B.; Carrasco, A.; Martinez-Gutierrez, R.; Tomas, V.; Tudela, J. Thymus mastichina L. essential oils from Murcia (Spain): Composition and antioxidant, antienzymatic and antimicrobial bioactivities. PLoS ONE 2018, 13, e0190790. [CrossRef] [PubMed]

109. De Oliveira, T.M.; de Carvalho, R.B.F.; da Costa, I.H.F.; de Oliveira, G.A.L.; de Souza, A.A.; de Lima, S.G.; de Freitas, R.M. Evaluation of p-cymene, a natural antioxidant. Pharm. Biol. 2015, 53, 423-428. [CrossRef] [PubMed]

110. Agus, H.H.; Sengoz, C.O.; Yilmaz, S. Oxidative stress-mediated apoptotic cell death induced by camphor in sod1-deficient Schizosaccharomyces pombe. Toxicol. Res. (Camb). 2018, 8, 216-226. [CrossRef] [PubMed]

111. Sabogal-Guáqueta, A.M.; Hobbie, F.; Keerthi, A.; Oun, A.; Kortholt, A.; Boddeke, E.; Dolga, A. Linalool attenuates oxidative stress and mitochondrial dysfunction mediated by glutamate and NMDA toxicity. Biomed. Pharmacother. 2019, 118, 109295. [CrossRef]

112. Elmann, A.; Mordechay, S.; Rindner, M.; Larkov, O.; Elkabetz, M.; Ravid, U. Protective effects of the essential oil of Salvia fruticosa and its constituents on astrocytic susceptibility to hydrogen peroxide-induced cell death. J. Agric. Food Chem. 2009, 57, 6636-6641. [CrossRef] [PubMed]

113. Ames-Sibin, A.P.; Barizão, C.L.; Castro-Ghizoni, C.V.; Silva, F.M.S.; Sá-Nakanishi, A.B.; Bracht, L.; Bersani-Amado, C.A.; Marçal-Natali, M.R.; Bracht, A.; Comar, J.F. $\beta$-caryophyllene, the major constituent of copaiba oil, reduces systemic inflammation and oxidative stress in arthritic rats. J. Cell. Biochem. 2018, 119, 10262-10277. [CrossRef] [PubMed]

114. Yu, X.; Lin, H.; Wang, Y.; Lv, W.; Zhang, S.; Qian, Y.; Deng, X.; Feng, N.; Yu, H.; Qian, B. d-limonene exhibits antitumor activity by inducing autophagy and apoptosis in lung cancer. Onco. Targets. Ther. 2018, 11, 1833-1847. [CrossRef]

115. Berliocchi, L.; Chiappini, C.; Adornetto, A.; Gentile, D.; Cerri, S.; Russo, R.; Bagetta, G.; Corasaniti, M.T. Early LC3 lipidation induced by d-limonene does not rely on mTOR inhibition, ERK activation and ROS production and it is associated with reduced clonogenic capacity of SH-SY5Y neuroblastoma cells. Phytomedicine 2018, 40, 98-105. [CrossRef]

116. Russo, R.; Cassiano, M.G.V.; Ciociaro, A.; Adornetto, A.; Varano, G.P.; Chiappini, C.; Berliocchi, L.; Tassorelli, C.; Bagetta, G.; Corasaniti, M.T. Role of D-Limonene in autophagy induced by bergamot essential oil in SH-SY5Y neuroblastoma cells. PLoS ONE 2014, 9, e113682. [CrossRef] [PubMed]

117. Lenis-Rojas, O.A.; Robalo, M.P.; Tomaz, A.I.; Carvalho, A.; Fernandes, A.R.; Marques, F.; Folgueira, M.; Yáñez, J.; Vázquez-García, D.; López Torres, M.; et al. RuII(p-cymene) compounds as effective and selective anticancer candidates with no toxicity in Vivo. Inorg. Chem. 2018, 57, 13150-13166. [CrossRef] [PubMed]

118. Edeler, D.; Arlt, S.; Petković, V.; Ludwig, G.; Drača, D.; Maksimović-Ivanić, D.; Mijatović, S.; Kaluđerović, G.N. Delivery of $[\mathrm{Ru}(\eta 6-\mathrm{p}$-cymene $) \mathrm{Cl} 2\{\mathrm{Ph} 2 \mathrm{P}(\mathrm{CH} 2) 3 \mathrm{SPh}-\mathrm{kP}\}]$ using unfunctionalized and mercapto functionalized SBA-15 mesoporous silica: Preparation, characterization and in vitro study. J. Inorg. Biochem. 2018, 180, 155-162. [CrossRef]

119. Ağuş, H.H.; Yilmaz, S.; Şengöz, C.O. Crosstalk between autophagy and apoptosis induced by camphor in Schizosaccharomyces pombe. Turkish J. Biol. Turk Biyol. Derg. 2019, 43, 382-390. [CrossRef] [PubMed]

120. Yu, B.; Ruan, M.; Liang, T.; Huang, S.-W.; Yu, Y.; Cheng, H.-B.; Shen, X.-C. The synergic effect of tetramethylpyrazine phosphate and borneol for protecting against ischemia injury in cortex and hippocampus regions by modulating apoptosis and autophagy. J. Mol. Neurosci. 2017, 63, 70-83. [CrossRef] [PubMed]

121. Chang, T.-L.; Liou, P.-S.; Cheng, P.-Y.; Chang, H.-N.; Tsai, P.-J. Borneol andluteolin from Chrysanthemum morifolium regulate ubiquitin signal degradation. J. Agric. Food Chem. 2018, 66, 8280-8290. [CrossRef] [PubMed] 
122. Yang, H.; Woo, J.; Pae, A.N.; Um, M.Y.; Cho, N.-C.; Park, K.D.; Yoon, M.; Kim, J.; Lee, C.J.; Cho, S. $\alpha$-pinene, a major constituent of pine tree oils, enhances non-rapid eye movement sleep in mice through GABA-benzodiazepine receptors. Mol. Pharmacol. 2016, 90, 530-539. [CrossRef] [PubMed]

123. Xu, Q.; Li, M.; Yang, M.; Yang, J.; Xie, J.; Lu, X.; Wang, F.; Chen, W. $\alpha$-pinene regulates miR-221 and induces G(2)/M phase cell cycle arrest in human hepatocellular carcinoma cells. Biosci. Rep. 2018, 38, BSR20180980. [CrossRef]

124. Woo, J.; Yang, H.; Yoon, M.; Gadhe, C.G.; Pae, A.N.; Cho, S.; Lee, C.J. 3-Carene, a phytoncide from pine tree has a sleep-enhancing effect by targeting the GABA(A)-benzodiazepine receptors. Exp. Neurobiol. 2019, 28, 593-601. [CrossRef] [PubMed]

125. Kobayashi, N.F.K. Macrophages in inflammation. Curr. Drug Targets Inflamm. Allergy 2005, 4, 281-286.

126. Archer, C.W.; Francis-West, P. The chondrocyte. Int. J. Biochem. Cell Biol. 2003, 35, 401-404. [CrossRef]

127. Baeuerle, P.A.; Baichwal, V.R. NF-kappa B as a frequent target for immunosuppressive and anti-inflammatory molecules. Adv. Immunol. 1997, 65, 111-137. [PubMed]

128. Hur, J.; Pak, S.C.; Koo, B.-S.; Jeon, S. Borneol alleviates oxidative stress via upregulation of Nrf2 and Bcl-2 in SH-SY5Y cells. Pharm. Biol. 2013, 51, 30-35. [CrossRef] [PubMed]

129. Lou, J.; Cao, G.; Li, R.; Liu, J.; Dong, Z.; Xu, L. $\beta$-caryophyllene attenuates focal cerebral ischemia-reperfusion injury by Nrf2/HO-1 pathway in rats. Neurochem. Res. 2016, 41, 1291-1304. [CrossRef]

130. Porres-Martinez, M.; Gonzalez-Burgos, E.; Carretero, M.E.; Gomez-Serranillos, M.P. In vitro neuroprotective potential of the monoterpenes alpha-pinene and 1,8-cineole against $\mathrm{H} 2 \mathrm{O} 2$-induced oxidative stress in PC12 cells. Z. Naturforsch. C. 2016, 71, 191-199. [CrossRef]

131. Jiang, Z.; Guo, X.; Zhang, K.; Sekaran, G.; Cao, B.; Zhao, Q.; Zhang, S.; Kirby, G.M.; Zhang, X. The essential oils and eucalyptol from Artemisia vulgaris L. prevent acetaminophen-induced liver injury by activating Nrf2-Keap1 and enhancing APAP clearance through non-toxic metabolic pathway. Front. Pharmacol. 2019, 10, 782. [CrossRef]

132. Xu, H.; Blair, N.T.; Clapham, D.E. Camphor activates and strongly desensitizes the transient receptor potential vanilloid subtype 1 channel in a vanilloid-independent mechanism. J. Neurosci. 2005, 25, 8924-8937. [CrossRef]

133. Sherkheli, M.A.; Benecke, H.; Doerner, J.F.; Kletke, O.; Vogt-Eisele, A.K.; Gisselmann, G.; Hatt, H. Monoterpenoids induce agonist-specific desensitization of transient receptor potential vanilloid-3 (TRPV3) ion channels. J. Pharm. Pharm. Sci. 2009, 12, 116-128. [CrossRef]

134. Riera, C.E.; Menozzi-Smarrito, C.; Affolter, M.; Michlig, S.; Munari, C.; Robert, F.; Vogel, H.; Simon, S.A.; le Coutre, J. Compounds from Sichuan and Melegueta peppers activate, covalently and non-covalently, TRPA1 and TRPV1 channels. Br. J. Pharmacol. 2009, 157, 1398-1409. [CrossRef] [PubMed]

135. Kaimoto, T.; Hatakeyama, Y.; Takahashi, K.; Imagawa, T.; Tominaga, M.; Ohta, T. Involvement of transient receptor potential A1 channel in algesic and analgesic actions of the organic compound limonene. Eur. J. Pain 2016, 20, 1155-1165. [CrossRef] [PubMed]

136. Bujak, J.K.; Kosmala, D.; Szopa, I.M.; Majchrzak, K.; Bednarczyk, P. Inflammation, cancer and immunity-implication of TRPV1 channel. Front. Oncol. 2019, 9, 1087. [CrossRef] [PubMed]

137. Turcotte, C.; Blanchet, M.-R.; Laviolette, M.; Flamand, N. The CB(2) receptor and its role as a regulator of inflammation. Cell. Mol. Life Sci. 2016, 73, 4449-4470. [CrossRef]

138. Trachootham, D.; Lu, W.; Ogasawara, M.A.; Nilsa, R.-D.V.; Huang, P. Redox regulation of cell survival. Antioxid. Redox Signal. 2008, 10, 1343-1374. [CrossRef]

139. Balaban, R.S.; Nemoto, S.; Finkel, T. Mitochondria, oxidants, and aging. Cell 2005, 120, 483-495. [CrossRef]

140. Schieber, M.; Chandel, N.S. ROS function in redox signaling and oxidative stress. Curr. Biol. 2014, 24, R453-R462. [CrossRef]

141. Miguel, M.G. Antioxidant and anti-inflammatory activities of essential oils: A short review. Molecules 2010, 15, 9252-9287. [CrossRef]

142. Pisoschi, A.M.; Pop, A.; Cimpeanu, C.; Predoi, G. Antioxidant capacity determination in plants and plant-derived products: A review. Oxid. Med. Cell. Longev. 2016, 2016, 9130976. [CrossRef]

143. Lin, J.-J.; Hsu, S.-C.; Lu, K.-W.; Ma, Y.-S.; Wu, C.-C.; Lu, H.-F.; Chen, J.-C.; Lin, J.-G.; Wu, P.-P.; Chung, J.-G. Alpha-phellandrene-induced apoptosis in mice leukemia WEHI-3 cells in vitro. Environ. Toxicol. 2016, 31, 1640-1651. [CrossRef] 
144. Ravanan, P.; Srikumar, I.F.; Talwar, P. Autophagy: The spotlight for cellular stress responses. Life Sci. 2017, 188, 53-67. [CrossRef]

145. Allen, E.A.; Baehrecke, E.H. Autophagy in animal development. Cell Death Differ. 2020, 27, 1-16. [CrossRef]

146. Deretic, V.; Levine, B. Autophagy balances inflammation in innate immunity. Autophagy 2018, 14, $243-251$. [CrossRef] [PubMed]

147. Zhang, Q.; Wu, D.; Wu, J.; Ou, Y.; Mu, C.; Han, B.; Zhang, Q. Improved blood-brain barrier distribution: Effect of borneol on the brain pharmacokinetics of kaempferol in rats by in vivo microdialysis sampling. J. Ethnopharmacol. 2015, 162, 270-277. [CrossRef] [PubMed]

148. Yu, B.; Ruan, M.; Liang, T.; Huang, S.-W.; Liu, S.-J.; Cheng, H.-B.; Shen, X.-C. Tetramethylpyrazine phosphate and borneol combination therapy synergistically attenuated ischemia-reperfusion injury of the hypothalamus and striatum via regulation of apoptosis and autophagy in a rat model. Am. J. Transl. Res. 2017, 9, 4807-4820. [PubMed]

149. Suh, K.S.; Chon, S.; Choi, E.M. Limonene attenuates methylglyoxal-induced dysfunction in MC3T3-E1 osteoblastic cells. Food Agric. Immunol. 2017, 28, 1256-1268. [CrossRef]

150. Martin, H. Role of PPAR-gamma in inflammation. Prospects for therapeutic intervention by food components. Mutat. Res. Mol. Mech. Mutagen. 2010, 690, 57-63. [CrossRef]

151. Tabet, N. Acetylcholinesterase inhibitors for Alzheimer's disease: Anti-inflammatories in acetylcholine clothing! Age Ageing 2006, 35, 336-338. [CrossRef]

152. Kalb, A.; von Haefen, C.; Sifringer, M.; Tegethoff, A.; Paeschke, N.; Kostova, M.; Feldheiser, A.; Spies, C.D. Acetylcholinesterase inhibitors reduce neuroinflammation and -degeneration in the cortex and hippocampus of a surgery stress rat model. PLoS ONE 2013, 8, e62679. [CrossRef]

153. Martinez, F.D. Genes, environments, development and asthma: A reappraisal. Eur. Respir. J. 2007, 29, 179-184. [CrossRef]

154. World Health Organization. Asthma. Fact sheet No. 307; Geneva, Swizerland. 2011. Available online: https://www.who.int/en/news-room/fact-sheets/detail/asthma. (accessed on 10 January 2020).

155. Douglas, J.G. Asthma; Manson Pub: London, UK, 2010.

156. Ober, C.; Hoffjan, S. Asthma genetics 2006: The long and winding road to gene discovery. Genes Immun. 2006, 7, 95-100. [CrossRef] [PubMed]

157. Quirt, J.; Hildebrand, K.J.; Mazza, J.; Noya, F.; Kim, H. Asthma. Allergy Asthma. Clin. Immunol. 2018, $14,50$. [CrossRef] [PubMed]

158. Hirota, R.; Nakamura, H.; Bhatti, S.A.; Ngatu, N.R.; Muzembo, B.A.; Dumavibhat, N.; Eitoku, M.; Sawamura, M.; Suganuma, N. Limonene inhalation reduces allergic airway inflammation in Dermatophagoides farinae-treated mice. Inhal. Toxicol. 2012, 24, 373-381. [CrossRef]

159. Chi, T.; Ji, X.; Xia, M.; Rong, Y.; Qiu, F.Z.L. Effect of six extractions from Wuhu decoction on isolated tracheal smooth muscle in guinea pig. Zhong Guo Shi Yan Fang Ji Xue Za Zhi 2009, 15, 52-55.

160. Falk, A.A.; Hagberg, M.T.; Lof, A.E.; Wigaeus-Hjelm, E.M.; Wang, Z.P. Uptake, distribution and elimination of alpha-pinene in man after exposure by inhalation. Scand. J. Work. Environ. Health 1990, 16, 372-378. [CrossRef]

161. Worth, H.; Dethlefsen, U. Patients with asthma benefit from concomitant therapy with cineole: A placebo-controlled, double-blind trial. J. Asthma 2012, 49, 849-853. [CrossRef] [PubMed]

162. Juergens, U.R. Anti-inflammatory properties of the monoterpene 1.8-cineole: Current evidence for co-medication in inflammatory airway diseases. Drug Res. (Stuttg). 2014, 64, 638-646. [CrossRef]

163. Chen, N.; Sun, G.; Yuan, X.; Hou, J.; Wu, Q.; Soromou, L.W.; Feng, H. Inhibition of lung inflammatory responses by bornyl acetate is correlated with regulation of myeloperoxidase activity. J. Surg. Res. 2014, 186, 436-445. [CrossRef]

164. Thomas, M. Allergic rhinitis: Evidence for impact on asthma. BMC Pulm. Med. 2006, 6 (Suppl. 1), S4. [CrossRef]

165. Nam, S.-Y.; Chung, C.; Seo, J.-H.; Rah, S.-Y.; Kim, H.-M.; Jeong, H.-J. The therapeutic efficacy of $\alpha$-pinene in an experimental mouse model of allergic rhinitis. Int. Immunopharmacol. 2014, 23, 273-282. [CrossRef]

166. Rohr, A.C.; Wilkins, C.K.; Clausen, P.A.; Hammer, M.; Nielsen, G.D.; Wolkoff, P.; Spengler, J.D. Upper airway and pulmonary effects of oxidation products of $(+)-\alpha$-pinene, $\mathrm{d}$-limonene, and isoprene in BALB/c mice. Inhal. Toxicol. 2002, 14, 663-684. [CrossRef] [PubMed] 
167. Cakmak, S.; Dales, R.E.; Liu, L.; Kauri, L.M.; Lemieux, C.L.; Hebbern, C.; Zhu, J. Residential exposure to volatile organic compounds and lung function: Results from a population-based cross-sectional survey. Environ. Pollut. 2014, 194, 145-151. [CrossRef] [PubMed]

168. National Institute of Arthritis and Musculoskeletal and Skin Diseases. Handout on Health: Atopic Dermatitis (A Type of Eczema). 2013. Available online: https://www.niams.nih.gov/health-topics/atopic-dermatitis/ advanced. (accessed on 5 January 2020).

169. Lee, G.N. and J. Atopic Dermatitis and Cytokines: The immunoregulatory and therapeutic implications of cytokines in atopic dermatitis-part II: Negative regulation and cytokine therapy in atopic dermatitis. Recent Pat. Inflamm. Allergy Drug Discov. 2012, 6, 248-261. [CrossRef] [PubMed]

170. Jin, H.; He, R.; Oyoshi, M.; Geha, R.S. Animal models of atopic dermatitis. J. Invest. Dermatol. 2009, 129, 31-40. [CrossRef]

171. Amagai, Y.; Katsuta, C.; Nomura, Y.; Oida, K.; Matsuda, K.; Jang, H.; Ahn, G.; Hamasaki, T.; Matsuda, H.; Tanaka, A. Amelioration of atopic-like skin conditions in NC/Tnd mice by topical application with distilled Alpinia intermedia Gagnep extracts. J. Dermatol. 2017, 44, 1238-1247. [CrossRef]

172. Kang, N.-J.; Han, S.-C.; Yoon, S.-H.; Sim, J.-Y.; Maeng, Y.H.; Kang, H.-K.; Yoo, E.-S. Cinnamomum camphora leaves alleviate allergic skin inflammatory responses In Vitro and In Vivo. Toxicol. Res. 2019, 35, $279-285$. [CrossRef]

173. Mihara, S.; Yamamoto, T.N.O. Inhibitory effects of the volatile compounds on allergic rhinitis—a consideration of the role of TRPA1 expressed in sensory nerve cell. Fragr J. 2013, 41, 59-65.

174. Takaishi, M.; Uchida, K.; Fujita, F.; Tominaga, M. Inhibitory effects of monoterpenes on human TRPA1 and the structural basis of their activity. J. Physiol. Sci. 2014, 64, 47-57. [CrossRef]

175. Wei, Q.J.; Wei, C.N.; Harada, K.; Minamoto, K.; Okamoto, Y.; Otsuka, M.; Ueda, A. Evaluation of allergenicity of constituents of myoga using the murine local lymph node assay. Int. J. Immunopathol. Pharmacol. 2010, 23, 463-470. [CrossRef]

176. Pesonen, M.; Suomela, S.; Kuuliala, O.; Henriks-Eckerman, M.-L.; Aalto-Korte, K. Occupational contact dermatitis caused by D-limonene. Contact Dermatitis 2014, 71, 273-279. [CrossRef]

177. Dharmagunawardena, B.; Takwale, A.; Sanders, K.J.; Cannan, S.; Rodger, A.; Ilchyshyn, A. Gas chromatography: An investigative tool in multiple allergies to essential oils. Contact Dermatitis 2002, 47, 288-292. [CrossRef] [PubMed]

178. Matura, M.; Sköld, M.; Börje, A.; Andersen, K.E.; Bruze, M.; Frosch, P.; Goossens, A.; Johansen, J.D.; Svedman, C.; White, I.R.; et al. Selected oxidized fragrance terpenes are common contact allergens. Contact Dermatitis 2005, 52, 320-328. [CrossRef] [PubMed]

179. Rudbäck, J.; Bergström, M.A.; Börje, A.; Nilsson, U.; Karlberg, A.-T. $\alpha$-terpinene, an antioxidant in tea tree oil, autoxidizes rapidly to skin allergens on air exposure. Chem. Res. Toxicol. 2012, 25, 713-721. [CrossRef] [PubMed]

180. Guo, Q.; Wang, Y.; Xu, D.; Nossent, J.; Pavlos, N.J.; Xu, J. Rheumatoid arthritis: Pathological mechanisms and modern pharmacologic therapies. Bone Res. 2018, 6, 15. [CrossRef]

181. Walia, M.; Mann, T.S.; Kumar, D.; Agnihotri, V.K.; Singh, B. Chemical composition and in vitro cytotoxic activity of essential oil of leaves of Malus domestica growing in western Himalaya (India). Evidence Based Complement. Altern. Med. 2012, 2012, 649727. [CrossRef]

182. Rufino, A.T.; Ribeiro, M.; Judas, F.; Salgueiro, L.; Lopes, M.C.; Cavaleiro, C.; Mendes, A.F. Anti-inflammatory and chondroprotective activity of (+)- $\alpha$-pinene: Structural and enantiomeric selectivity. J. Nat. Prod. 2014, 77, 264-269. [CrossRef]

183. Cho, K.S.; Lee, J.H.; Cho, J.; Song*, G.-H.C. and G.J. Autophagy modulators and neuroinflammation. Curr. Med. Chem. 2018, 25, 1-25.

184. Tansey, M.G.; McCoy, M.K.; Frank-Cannon, T.C. Neuroinflammatory mechanisms in Parkinson's disease: Potential environmental triggers, pathways, and targets for early therapeutic intervention. Exp. Neurol. 2007, 208, 1-25. [CrossRef]

185. Kraft, A.D.; Harry, G.J. Features of microglia and neuroinflammation relevant to environmental exposure and neurotoxicity. Int. J. Environ. Res. Public Health 2011, 8, 2980-3018. [CrossRef]

186. Cabral, G.A.; Griffin-Thomas, L. Emerging role of the cannabinoid receptor CB2 in immune regulation: Therapeutic prospects for neuroinflammation. Expert Rev. Mol. Med. 2009, 11, e3. [CrossRef] 
187. Youssef, D.A.; El-Fayoumi, H.M.; Mahmoud, M.F. Beta-caryophyllene alleviates diet-induced neurobehavioral changes in rats: The role of CB2 and PPAR- $\gamma$ receptors. Biomed. Pharmacother. 2019, 110, 145-154. [CrossRef] [PubMed]

188. Singh, H.P.; Batish, D.R.; Kaur, S.; Arora, K.; Kohli, R.K. Alpha-pinene inhibits growth and induces oxidative stress in roots. Ann. Bot. 2006, 98, 1261-1269. [CrossRef] [PubMed]

189. Somade, O.; Ogunberu, D.; Fakayode, T.; Animashaun, A. Edible camphor-induced histopathological changes in hippocampus and cerebral cortex following oral administration into rats. J. Interdiscip. Histopathol. 2017, 5, 7-11. [CrossRef]

190. Fritz, T.M.; Burg, G.; Krasovec, M. Allergic contact dermatitis to cosmetics containing Melaleuca alternifolia (tea tree oil). Ann. Dermatol. Venereol. 2001, 128, 123-126.

191. Valente, J.; Zuzarte, M.; Gonçalves, M.J.; Lopes, M.C.; Cavaleiro, C.; Salgueiro, L.; Cruz, M.T. Antifungal, antioxidant and anti-inflammatory activities of Oenanthe crocata L. essential oil. Food Chem. Toxicol. 2013, 62, 349-354. [CrossRef]

(C) 2020 by the authors. Licensee MDPI, Basel, Switzerland. This article is an open access article distributed under the terms and conditions of the Creative Commons Attribution (CC BY) license (http://creativecommons.org/licenses/by/4.0/). 